SILVA, Lucas do Monte. O corrupto como inimigo no direito penal brasileiro. Revista Eletrônica Direito e Política, Programa de Pós-Graduação Stricto Sensu em Ciência Jurídica da UNIVALI, Itajaí, v.10, n.3, $2^{\circ}$ quadrimestre de 2015. Disponível em: www.univali.br/direitoepolitica - ISSN 19807791.

\title{
O CORRUPTO COMO INIMIGO NO DIREITO PENAL BRASILEIRO
}

\author{
THE CORRUPT AS AN ENEMY OF THE BRAZILIAN CRIMINAL LAW
}

\section{Lucas do Monte Silva ${ }^{1}$}

SUMÁRIO: Introdução; 1 A corrupção no Brasil; 2 A tutela do bem jurídico "moralidade administrativa", Direito Penal simbólico e a expansão do Direito Penal; 3 O corrupto é um inimigo no Direito Penal brasileiro?; Considerações Finais; Referências das fontes citadas.

\section{RESUMO}

Em função da Sociedade de Riscos e da desmaterialização do bem jurídico, o Direito Penal, hodiernamente, se expande, por meio da administrativização do fenômeno delitivo, buscando tutelar tanto os crimes já cometidos, como prevenir os riscos possíveis de futuros delitos que possam afetar bens jurídicos regidos por esse ramo, sobretudo, bens transindividuais de difícil limitação, como crimes praticados contra a ordem econômica e contra a ordem ambiental. Ocorre que, além dessas consequências, também se verificam mudanças processuais, notadamente, a visão do sujeito que praticou um ato de corrupção como um inimigo da sociedade brasileira e, consequentemente, do Direito Penal. De acordo com este discurso do senso comum midiático, abre-se azo para que seja possível mitigar direitos e garantias fundamentais do réu em prol da sociedade. O objetivo do artigo, portanto, é verificar o processo de construção da imagem do inimigo no corrupto, de forma a constatar sua existência no cenário brasileiro ou se seria apenas uma falácia. Dessa forma, por meio da metodologia bibliográfica e do método hipotético-dedutivo, o texto busca analisar os fundamentos por trás da criação da imagem do corrupto como inimigo, bem como se os fundamentos dessa nova visão na sociedade brasileira.

PALAVRAS-CHAVE: Direito Penal do Inimigo. Corrupção. Bem jurídico. Moralidade Administrativa.

\section{ABSCTRACT}

From the Risk Society and the dematerialization of the legal interest, the

\footnotetext{
${ }^{1}$ Acadêmico do curso de Direito da Universidade Federal do Rio Grande do Norte (UFRN). Bolsista do Conselho Nacional de Desenvolvimento Científico e Tecnológico, na base da pesquisa "Direito e Desenvolvimento" da UFRN. Membro da Equipe Editorial da Revista Direito e Liberdade, publicada pela Escola de Magistratura do Rio Grande do Norte (ESMARN).
} 
SILVA, Lucas do Monte. O corrupto como inimigo no direito penal brasileiro. Revista Eletrônica Direito e Política, Programa de Pós-Graduação Stricto Sensu em Ciência Jurídica da UNIVALI, Itajaí, v.10, n.3, $2^{\circ}$ quadrimestre de 2015. Disponível em: www.univali.br/direitoepolitica - ISSN 19807791.

Criminal law has been expanding, through the creation of the criminal phenomenon in cases that should be resolved in other legal fields, seeking to protect not only crimes already committed, but also to prevent possible risks that may occur and damage any legal interest tutored by this branch of Law, especially transindividual rights that are difficult to limitate, such as crimes committed against the economic, as an example. It turns out that in addition to these consequences, it also occurs criminal procedural changes, notably the subject of the Criminal Law who committed an act of corruption becomes an enemy of the society and, consequently, of the Criminal Law. Thus, it allows the mitigation of rights and guarantees in favor of society. The article aims to verify the process of construction of the enemy's image in the "corrupt" figure in order to see whether, in the Brazilian scenario, this can be observed, or it can be considered a fallacy. Thus, using the bibliographical methodology and hiphotetical-deductive method, this article seeks to analyze the reasons behind the corrupt's image creation as an enemy, as well as if the judiciary, may, within the principle of legality, produce some changes in this scenario.

KEYWORDS: Criminal Law of the Enemy. Corruption. Legal interest. Administrative morality.

\section{INTRODUÇÃO}

Em função da Sociedade de Riscos e da desmaterialização do bem jurídico, o Direito Penal, hodiernamente, se expande, por meio da administrativização do fenômeno delitivo, buscando tutelar tanto os crimes já cometidos, como prevenir os riscos possíveis de futuros delitos que possam afetar bens jurídicos regidos por esse ramo, sobretudo, bens transindividuais de difícil limitação, como crimes praticados contra a ordem econômica e contra a ordem ambiental. Ocorre que, além dessas consequências, também se verificam mudanças processuais, notadamente, a visão do sujeito que praticou um ato de corrupção como um inimigo da sociedade brasileira e, consequentemente, do Direito Penal.

De acordo com este discurso do senso midiático, baseado na ideologia da defesa social, mostra-se possível mitigar direitos e garantias fundamentais em prol sociedade. O objetivo do artigo é verificar o processo de construção da imagem do inimigo no corrupto, de forma a constatar sua existência no cenário brasileiro ou se seria apenas uma falácia. 
SILVA, Lucas do Monte. O corrupto como inimigo no direito penal brasileiro. Revista Eletrônica Direito e Política, Programa de Pós-Graduação Stricto Sensu em Ciência Jurídica da UNIVALI, Itajaí, v.10, n.3, $2^{\circ}$ quadrimestre de 2015. Disponível em: www.univali.br/direitoepolitica - ISSN 19807791.

Dessa forma, por meio da metodologia bibliográfica e do método hipotéticodedutivo, o texto busca analisar os fundamentos por trás da criação da imagem do corrupto como inimigo.

O texto se divide em três seções. Primeiramente, serão feitas considerações sobre a corrupção no cenário brasileiro, analisando seus fundamentos e o porquê da sua infiltração em diversas instituições dessa nação. Em seguida, discute-se a tutela do bem jurídico "moralidade administrativa", analisando seu conceito e se poderia efetivamente ser considerado um bem jurídico passível de tutela pelo Direito Penal. Além disso, discute-se o Direito Penal Simbólico e a expansão do Direito Penal, tendo por base a administrativização do Direito e a desmaterialização do bem jurídico. Por fim, analisa-se se o corrupto poderia ser considerado um inimigo no Direito Penal. Para tanto, disserta-se sobre os crimes de colarinho branco e sua nocividade social, o referencial teórico do Direito Penal do Inimigo, de forma a permitir que seja possível analisar os atributos de um "inimigo", para, por fim, responder a indagação tema deste trabalho.

\section{A CORRUPÇÃO NO BRASIL}

A corrupção no Brasil não é novidade. Desde a época da colonização portuguesa, os valores individualistas dos cidadãos da metrópole, destacados na figura do rei e dos representantes da coroa, foram transportados e reproduzidos no cenário brasileiro. Estes se baseavam na "aversão ao trabalho sistemático, o gosto pela luxúria, o desejo intenso pelo desfrute dos bens, a degradação dos costumes e a impunidade dos crimes", de maneira que a corrupção nacional tornou-se uma "decorrência da moral predatória caracteristicamente dominante no Estado patrimonial, que, conscientemente ou não, formatou um conjunto de padrões sociopolíticos de comportamento ético adverso às formas racionais mais modernas de trato da res pública". ${ }^{2}$

Assim, abre-se azo para a confusão entre o público e o privado, de tal forma que há uma institucionalização da corrupção e, em razão de determinados

2 GHIZZO NETO, Affonso. Corrupção, Estado Democrático de Direito e Educação. 2008. $290 \mathrm{f}$. Dissertação (Mestrado em Direito) - Universidade Federal de Santa Catarina, Santa Catarina, p. 10. 
SILVA, Lucas do Monte. O corrupto como inimigo no direito penal brasileiro. Revista Eletrônica Direito e Política, Programa de Pós-Graduação Stricto Sensu em Ciência Jurídica da UNIVALI, Itajaí, v.10, n.3, $2^{\circ}$ quadrimestre de 2015. Disponível em: www.univali.br/direitoepolitica - ISSN 19807791.

motivos institucionais, a banalização da pena, devido à impunidade 3 . O bem público que deveria ser de "todos", torna-se de ninguém. Ocorre que os detentores do poder, de maneira unilateral, apropriam-se das coisas públicas, dos seus cargos, prerrogativas e funções, de modo a tornar dificultosa a separação entre o público e o privado.

Nesse contexto, na prática, as prerrogativas funcionais deixam de ser apenas pelo cargo exercido pelo seu titular (da forma que deveria ser) e tornam-se pessoais. ${ }^{4}$ Nesse sentido, Weber salienta que "o temor de perder o conjunto dessas vantagens é a razão decisiva da solidariedade que liga o estado-maior administrativo aos detentores do poder". ${ }^{5}$ Ademais, as decisões não são feitas com base nos limites do Estado Democrático de Direito; ao revés, tomam-se decisões arbitrárias e, em seguida, busca-se justificá-las, por argumentos vagos de conveniência e oportunidade. ${ }^{6}$

Essas questões podem ser observadas, por excelência, com o preenchimento dos cargos de confiança da Administração Pública. O aparelhamento burocrático do Estado é utilizado como moeda de troca entre políticos. A titularidade de Ministérios, empresas públicas e secretarias, bem como os empregos neles existentes, são utilizados não pelo mérito e adequação entre os que pretendem exercer essa função e as necessidades atuais da população, mas sim, pelo partido político que ajudará, futuramente, governo, a passar determinado Projeto de Lei.

Nesse sentido, Ghizzo Neto anota que:

\footnotetext{
3 "A impunidade é característica marcante da estrutura do Estado patrimonial, sendo consequëencia lógica de sua dinaimica funcional. A impunidade, intimamente relacionada com o ordenamento jurídico adotado, é proveniente da omissão e da cumplicidade do grupo dirigente com as práticas delituosas. As relaç̃ões íntimas, os interesses comuns e as "razões de Estado" são circunstan̂cias determinantes para o aceite da transgressão do ordenamento, convertendo-se em estímulo à reprodução contínua e crescente dos mais variados delitos." GHIZZO NETO, Affonso. Corrupção, Estado Democrático de Direito e Educação. 2008. 290 f. Dissertação (Mestrado em Direito) Universidade Federal de Santa Catarina, Santa Catarina, p. 151).

4 GHIZZO NETO, Affonso. Corrupção, Estado Democrático de Direito e Educação. 2008. 290 f. Dissertação (Mestrado em Direito) - Universidade Federal de Santa Catarina, Santa Catarina, p. $151)$, p. 24

${ }^{5}$ WEBER, Max. A política como vocação. In: Ciencia e política: duas vocações. São Paulo, Cultrix, 2000, p. 60.

${ }^{6}$ Sobre a importância da argumentação para a prática jurídica, Cf. SILVA, Nailton Gomes. Método para compor e avaliar argumentos jurídicos. Revista Direito e Liberdade, Natal, v. 16, n. 3, p. 189-226, set./dez. 2014. Quadrimestral.
} 
SILVA, Lucas do Monte. O corrupto como inimigo no direito penal brasileiro. Revista Eletrônica Direito e Política, Programa de Pós-Graduação Stricto Sensu em Ciência Jurídica da UNIVALI, Itajaí, v.10, n.3, $2^{\circ}$ quadrimestre de 2015. Disponível em: www.univali.br/direitoepolitica - ISSN 19807791.

\begin{abstract}
O poder político nacional - patrimonial, por essência e tecnocrata por formalidade - comanda e governa as oportunidades e o próprio acesso às políticas públicas, conduzindo grande parcela de brasileiros à exclusão, política, econốmica e social, enfim, a diferentes formas de escravidão, sendo contínua a manipulação dos instrumentos de poder, consubstanciados através do assistencialismo, do clientelismo, do parasitismo etc. ${ }^{7}$
\end{abstract}

No Brasil, a situação é ainda mais complicada, pois, em diversos casos, a corrupção é confundida com o jeitinho brasileiro. Essa situação pode ser observada, de forma clara, no estudo da Pesquisa Social Brasileira, no qual no questionário da investigação foram apresentadas 19 situações para serem classificadas como jeitinho, favor ou corrupção, pelo grupo de mostra, formado por 2.363 pessoas, sendo $9 \%$ de analfabetos, $25 \%$ com até quarta série, $23 \%$ com escolaridade de quinta a oitava série, $31 \%$ com ensino médio e $12 \%$ com grau superior, habitantes de 102 municípios brasileiros. ${ }^{8}$

De acordo com os resultados do referido estudo, foram considerados atos de corrupção sete das situações apresentadas: a) usar um cargo no governo para enriquecer, com um índice de $90 \%$; b) pagar um funcionário de uma companhia de energia para fazer o relógio marcar um consumo menor, com um índice de $85 \%$; c) dar R\$20,00 (vinte reais) para um guarda para ele não aplicar uma multa, com um índice de $84 \%$; d) uma pessoa conseguir uma maneira de pagar menos impostos sem que o governo perceba, com um índice de $83 \%$; e) uma pessoa ter dois empregos, mas só vai trabalhar em um deles, com um índice de $78 \%$; f) fazer "gato", ou seja, uma gambiarra de energia elétrica, com um índice de $74 \%$; e g) uma pessoa ter uma bolsa de estudo e um emprego ao mesmo tempo, o que é proibido, mas ela consegue esconder do governo, com um índice de $74 \%$.

Enquanto, o "jeitinho brasileiro" foi configurado nas seguintes hipóteses: a) uma pessoa que costuma dar boas gorjetas ao garçom do restaurante para quando voltar não precisar esperar na fila, com um índice de 59\%; b) uma pessoa que

\footnotetext{
7 GHIZZO NETO, Affonso. Corrupção, Estado Democrático de Direito e Educação. 2008. 290 f. Dissertação (Mestrado em Direito) - Universidade Federal de Santa Catarina, Santa Catarina, p. 14

${ }^{8}$ ALMEIDA, Alberto Carlos. A cabeça do brasileiro. 2.ed. Rio de Janeiro: Record, 2007. p. 45-71.
} 
SILVA, Lucas do Monte. O corrupto como inimigo no direito penal brasileiro. Revista Eletrônica Direito e Política, Programa de Pós-Graduação Stricto Sensu em Ciência Jurídica da UNIVALI, Itajaí, v.10, n.3, $2^{\circ}$ quadrimestre de 2015. Disponível em: www.univali.br/direitoepolitica - ISSN 19807791.

trabalha em um banco ajudar um conhecido que tem pressa a passar na frente da fila, com um índice de $56 \%$; c) uma pessoa que conhece um médico passar na frente da fila do posto de saúde, com um índice de 50\%; d) uma mãe que conhece um funcionário da escola passar na frente da fila quando vai matricular seu filho, com um índice de 50\%; e) alguém consegue um empréstimo do governo que demora muito a sair. Consegue liberar o empréstimo mais rápido porque tem um parente no governo, com um índice de $45 \%$; e f) pedir a um amigo que trabalha no serviço público para ajudar a tirar um documento mais rápido do que o normal, com um índice de $43 \%$.

Observa-se que, do ponto de vista histórico-social, não há diferenças notáveis entre as hipóteses apresentadas. Em todas, o sujeito pratica uma conduta que está na linha tênue entre a legalidade e ilegalidade/antiética. A diferença jaz na aceitação dessas condutas na sociedade. ${ }^{9}$

Ocorre que a perda financeira da corrupção não se limita ao prejuízo ao erário, mas também a falta de confiança em relações sociais, conforme salienta Sutherland:

The financial loss from white-collar crime, great as it is, is less important than the damage to social relations. Whitecollar crimes violate trust and therefore create distrust, which lowers social morale and produces social disorganization on a large scale. Other crimes produce relatively little effect on social institutions or social organization $^{10}$.

Nos últimos anos, os casos que envolvem alguma forma de perversão da legalidade dos atos do Estado, englobados, em regra, pelo senso comum

\footnotetext{
9 Cf. "A corrupção, no seu sentido mais amplo, pode ser definida como a decomposição, o apodrecimento do estado padrão normal ou esperado, o processo ou efeito de corromper e alterar as características originais de uma coisa ou um procedimento. É a devassidão, degradação, depravação, prostituição e perversão de hábitos e costumes. Enfim, o suborno, a vantagem indevida, o engodo arquitetado, a peita, o processo ou efeito de corromper e alterar as características originais de uma coisa ou um procedimento. Sob as mais variadas formas e realces múltiplos, o fenômeno da corrupção campeia as diversas áreas da atividade humana, tanto na esfera pública, como na privada." GHIZZO NETO, Affonso. Corrupção, Estado Democrático de Direito e Educação. 2008. 290 f. Dissertação (Mestrado em Direito) Universidade Federal de Santa Catarina, Santa Catarina, p. 99.

${ }^{10}$ SUTHERLAND, Edwin H. White Collar Criminality. American Sociological Review. 1940;5:1-12, p. 5
} 
SILVA, Lucas do Monte. O corrupto como inimigo no direito penal brasileiro. Revista Eletrônica Direito e Política, Programa de Pós-Graduação Stricto Sensu em Ciência Jurídica da UNIVALI, Itajaí, v.10, n.3, $2^{\circ}$ quadrimestre de 2015. Disponível em: www.univali.br/direitoepolitica - ISSN 19807791.

midiático, no termo "corrupção", ganharam destaque, seja na mídia, seja na sociedade.

Exemplo dessa situação é o caso Lava Jato que vem sendo investigado nos últimos meses. Esse caso consiste na investigação de um esquema de lavagem de dinheiro e evasão de divisas que, segundo a Polícia Federal e o Ministério Público Federal, movimentou cerca de $\mathrm{R} \$ 10$ bilhões, sendo considerada a maior investigação de corrupção da história do País. ${ }^{11}$

No caso vertente, as grandes empreiteiras organizavam-se na forma de cartel e pagavam propina para altos executivos da Petrobras e outros agentes públicos, sobretudo de fiscalização. O valor dessa propina variava de $1 \%$ a $5 \%$ do montante total de contratos bilionários superfaturados. Assim, não existia competitividade, pois apenas as empreiteiras selecionadas participavam das licitações e, mesmo assim, ainda possuíam informações sigilosas, para facilitar ainda mais o procedimento licitatório. ${ }^{12}$

As investigações iniciais resultaram a partir da descoberta de um esquema de desvio de recursos da Petrobras, no qual segundo informações da Polícia Federal (PF) e o Ministério Público Federal (MPF), os dirigentes da estatal estariam envolvidos no pagamento de propina a políticos e executivos de empresas que firmaram contratos com a petroleira. Em 10 fases, já foram cumpridos mais de 350 mandados judiciais, incluindo prisões preventivas, temporárias, busca e apreensão e condução coercitiva.

Até o momento, o Juiz Federal Sérgio Moro, responsável pelos processos da Lava Jato na primeira instância, aceitou denúncia contra 82 pessoas.

Feito esse pano de fundo do contexto da corrupção no Brasil, cabe adentrar a tutela do Direito Penal aos bens jurídicos aqui apresentados, frisando-se, por oportuno, que as discussões feitas serão retornadas na quarta seção do presente artigo.

\footnotetext{
11 BRASIL. MINISTÉRIO PÚBLICO FEDERAL. Caso Lava Jato. Disponível em: <http://www.lavajato.mpf.mp.br>. Acesso em: 30 mar. 2015.

12 BRASIL. MINISTÉRIO PÚBLICO FEDERAL. Caso Lava Jato. Disponível em: <http://www.lavajato.mpf.mp.br>. Acesso em: 30 mar. 2015.
} 
SILVA, Lucas do Monte. O corrupto como inimigo no direito penal brasileiro. Revista Eletrônica Direito e Política, Programa de Pós-Graduação Stricto Sensu em Ciência Jurídica da UNIVALI, Itajaí, v.10, n.3, $2^{\circ}$ quadrimestre de 2015. Disponível em: www.univali.br/direitoepolitica - ISSN 19807791.

\section{A TUTELA DO BEM JURÍDICO "MORALIDADE ADMINISTRATIVA", DIREITO PENAL SIMBÓlico E A EXPANSÃo DO DIREITO PENAL}

O Direito Penal liberal clássico tinha como objetivo tutelar tão somente os bens jurídicos essenciais, quais sejam, vida, liberdade e segurança pessoal. Hodiernamente, nota-se que, na realidade, a política criminal brasileira vem seguindo a corrente contrária a esse pensamento. Observa-se uma expansão e administrativização das tutelas do Direito Penal. Tal administrativização do Direito Penal não é uma novidade nos estudos da Ciência Criminal. Cada vez mais esse ramo do Direito, considerando os conflitos do mundo pós-moderno ${ }^{13}$, vem trazendo ao seu bojo condutas que podiam (e deveriam) ser tuteladas por outras áreas do Direito, tal como o Direito Administrativo e o Direito Civil. ${ }^{14}$

O Código repressivo, nesse contexto, tipifica condutas de baixa periculosidade, que seguem no sentido contrário ao fundamento ontológico do Direito Penal, qual

\footnotetext{
${ }^{13}$ Entende-se a pós-modernidade como "a modernidade que atinge a maioridade, a modernidade olhando-se a distância e não de dentro, fazendo um inventário completo de ganhos e perdas, psicanalisando-se, descobrindo as intenções que jamais explicitara, descobrindo que elas são mutuamente incongruentes e se cancelam. A pós-modernidade é a modernidade chegando a um acordo com a sua própria impossibilidade, uma modernidade que se automonitora, que conscientemente descarta o que outrora fazia inconscientemente" (BAUMAN, Zygmunt: Modernidade e Ambivalência. Rio de Janeiro: Jorge Zahar Editor. 1999. p. 250). Ressalta-se que o termo pode ser " empregado para designar um tempo histórico, uma linha do pensamento filosófico que se opõe à modernidade, uma idéia que procura interpretar a realidade do mundo (multidisciplinar) sem abandonar o acervo do conhecimento que passou. Por fim, a PósModernidade representa um conjunto de idéias inovadoras que procura revisitar o pensamento da Modernidade." (DIAS, Maria da Graça dos Santos; MELO, Osvaldo Ferreira de; SILVA, Moacyr Motta da. Política jurídica e pós-modernidade. Florianópolis: Conceito Editorial, 2009. p. 128). Na área criminal, o termo se assemelha às consequências da sociedade de risco, na qual as "verdadeiras incertezas, reforçadas por rápidas inovações tecnológicas e respostas sociais aceleradas, estão criando uma nova paisagem de risco global. Em todas essas novas tecnologias incertas de risco, estamos separados da possibilidade e dos resultados por um oceano de ignorância" (BECK, Ulrich. Incertezas fabricadas - Entrevista com o sociólogo alemão Ulrich Beck. Disponível em: <http://www.jinnyat.com.br/artigos/a_sociedade_de_risco.pdf>. Acesso em: 15 jul 2015). Nesse sentido, Cf. GIDDENS, A. As Conseqüências da Modernidade. São Paulo: Editora da Universidade Estadual Paulista, 1991 e CRUZ, Paulo Márcio; GLASENAPP, Maikon Cristiano. Governança e sustentabilidade: constituindo novos paradigmas na pós-modernidade. Revista Direito e Liberdade, Natal, v. 16, n. 2, p. 163-186, maio/ago. 2014. Quadrimestral.
}

${ }^{14}$ Frise-se que "é indiscutível que a força conformadora dos comportamentos do direito civil e do direito administrativo é menor do que a do direito penal; como menor é, por isso, a força estabilizadora das expectativas comunitárias na manutenção da validade da norma violada, neste sentido, a sua força preventiva ou, mais especificamente, de «prevenção geral positiva ou de integração» Este é o fundamento último da máxima - liberal, mas simultaneamente social - da intervenção jurídico-penal como intervenção de ultima ratio. (DIAS, Jorge de Figueiredo. O papel do direito penal na proteção das gerações futuras.Boletim da Faculdade de Direito da Universidade de Coimbra-volume comemorativo do $75^{\circ}$ Volume, Coimbra (2003): 1123-1138. p. 49) 
SILVA, Lucas do Monte. O corrupto como inimigo no direito penal brasileiro. Revista Eletrônica Direito e Política, Programa de Pós-Graduação Stricto Sensu em Ciência Jurídica da UNIVALI, Itajaí, v.10, n.3, $2^{\circ}$ quadrimestre de 2015. Disponível em: www.univali.br/direitoepolitica - ISSN 19807791.

seja, ser ultima ratio, isto é, ser a última medida utilizada pelo Direito para regular determinada situação, no caso, crime, tornando-se sola ou prima ratio. ${ }^{15}$ Não há dúvida de que o Direito Penal deve ser ultima ratio, atuando tão somente quando os demais ramos do Direito se apresentarem incapazes de dar tutela satisfatória para os bens jurídicos que se busca proteger. Com essa acepção, o Poder Penal, conforme salienta Ferrajoli, estaria rigidamente limitado e vinculado à lei no plano substancial (isto é, aos conteúdos penalmente relevantes) e submetidos a um plano processual ${ }^{16}$. Dessa forma, o Poder Público somente poderia regular determinada situação se três requisitos fossem atendidos: a) regular um bem jurídico penalmente relevante, possuindo relevância no plano substancial da lei; b) outras esferas do Direito não consigam tutelá-lo de maneira satisfatória, isto é, não consigam evitar a prática de determinada conduta ou promover certo objetivo; c) se tratar de um situação jurídica que merece tratamento pelo Poder Penal, uma vez que nem todas as situações, mesmo que não consigam ser tuteladas para outras áreas do Direito, fazem jus à criação de um novo tipo penal, sendo possível sua regulação por outras esferas da Administração Pública, que não o Direito, de per se. ${ }^{17} \mathrm{Em}$ outras palavras: o comportamento deve possuir dignidade punitiva e deve constituir crime; caso não tenha a necessidade de ser punido, deve ser descriminalizados. ${ }^{18}$

15 ALVES, Fábio Wellington Ataíde. Efetivação da garantia de defesa no estado constitucional de direito: colisão entre poder punitivo e garantia de defesa. 2008. Dissertação (Mestrado)_ Universidade Federal do Rio Grande do Norte, p. 186. Nesse sentido, GIACOMO, afirma que "a função específica do Direito Penal na sociedade do risco é justamente o asseguramento do futuro em níveis de qualidade superior àquele que não experimentasse a sua intervenção. Negar a intervenção do Direito Penal para os novos riscos é inverter o princípio da ultima ratio, pois se subtrai da tutela penal condutas tão gravosas que põem em risco a vida como um todo." GIACOMO, Roberta Catarina; MACHADO, Fábio Guedes de Paula. Novas teses dogmáticas jurídico-penais para a proteção do bem jurídico ecológico na sociedade do risco. Revista Liberdades, v. 2, p. 39-55, 2009. p. 48.

${ }^{16}$ FERRAJOLI, Luigi. Direito e razão: teoria do garantismo penal. São Paulo: Revista dos Tribunais, 2002, p. 83

${ }^{17}$ Nota-se, por oportuno, a existência de corrente doutrinária contrária a posição aqui apresentada, capitaneada pelos ensinamentos do Law and Order. Para ela, o principal foco do Direito Penal é a regulação da ordem social, por meio da aplicação rigorosa da lei, visando a elimiação do crime, criminalidade e do criminoso. Trata-se de um Direito Penal "incondicionado e ili- mitado, é o que se caracteriza, além de sua excessiva severidade, pela incerteza e impre- visibilidade das condenações e das penas e que, conseqüentemente, configura-se como um sistema de poder não controlável racionalmente em face da ausência de parâmetros certos e racionais de convalidação e anulação (FERRAJOLI, Luigi. Direito e razão: teoria do garantismo penal. São Paulo: Revista dos Tribunais, 2002, p. 84)

18 DIAS, Jorge de Figueiredo. Temas Básicos da Doutrina Penal. Coimbra: Coimbra Editora, 2001, p. 140 
SILVA, Lucas do Monte. O corrupto como inimigo no direito penal brasileiro. Revista Eletrônica Direito e Política, Programa de Pós-Graduação Stricto Sensu em Ciência Jurídica da UNIVALI, Itajaí, v.10, n.3, $2^{\circ}$ quadrimestre de 2015. Disponível em: www.univali.br/direitoepolitica - ISSN 19807791.

Ocorre que, na pós-modernidade, os juristas encontram-se diante de duas celeumas: a) com os avanços tecnológicos, necessitam expandir os conceitos e a quantidade de bens jurídicos tutelados pelo Direito Penal, de forma a albergar situações que, outrora, não eram passíveis de serem tuteladas por essa área, seja pela inexistência de tecnologia para tanto, seja pela difusão cada vez maior de informações pelas redes sociais e de troca de mensagens, que necessitam que o Direito avance para tutelá-las; b) o sentimento de impunidade e injustiça da população. Embora por razões errôneas, ainda existe parcela da sociedade que defende o aumento do rigor da pena de todos os delitos, mesmo aqueles de baixa periculosidade, nos quais a pena privativa de liberdade, por exemplo, a priori, não possui qualquer serventia.

Diante dessas questões, ocorre uma expansão do Direito Penal, por meio da administrativização do fenômeno delitivo, buscando tutelar além dos crimes já cometidos, também prevenir os riscos possíveis de futuros delitos que possam afetar bem jurídico tutelado por esse ramo, sobretudo, bens transindividuais de difícil limitação, como crimes praticados contra a ordem econômica e contra a ordem ambiental"19. Assim, atendem-se aos "anseios sem guardar ressonância com qualquer projeto concreto de política criminal."20 Segundo Luz, tal movimento é:

(...) caracterizado pelo advento de interesses difusos e supraindividuais no âmbito de funcionamento do Direito Penal, é conhecido como desmaterialização do bem jurídico. Nele, evidencia-se uma crescente "criação estatal e artificial de bens jurídicos", que passam a ser cada vez mais

\footnotetext{
${ }^{19}$ Além disso, afirma que "para tanto, partem da premissa de que o Direito Penal deve ser limitado ao máximo, o que implica sua incidência apenas sobre aquelas condutas que violem, de maneira agressiva, os bens indispensáveis para a vida em comum, como a vida, a saúde, a propriedade etc. (GIACOMO, Roberta Catarina; MACHADO, Fábio Guedes de Paula. Novas teses dogmáticas jurídico-penais para a proteção do bem jurídico ecológico na sociedade do risco. Revista Liberdades, v. 2, p. 39-55, 2009, p. 40). Além disso, afirmam que: "concluindo-se a proposta de Hassemer, tem o escopo de afastar o Direito Penal da tarefa de gestão de riscos, reservando-se à repressão de ataques violentos e significativos a bens jurídicos fundamentais." (GIACOMO, Roberta Catarina; MACHADO, Fábio Guedes de Paula. Novas teses dogmáticas jurídico-penais para a proteção do bem jurídico ecológico na sociedade do risco. Revista Liberdades, v. 2, p. 3955,2009 , p. 42)

20 ALVES, Fábio Wellington Ataíde. Efetivação da garantia de defesa no estado constitucional de direito: colisão entre poder punitivo e garantia de defesa. 2008. Dissertação (Mestrado)_ Universidade Federal do Rio Grande do Norte. p. 190.
} 
SILVA, Lucas do Monte. O corrupto como inimigo no direito penal brasileiro. Revista Eletrônica Direito e Política, Programa de Pós-Graduação Stricto Sensu em Ciência Jurídica da UNIVALI, Itajaí, v.10, n.3, $2^{\circ}$ quadrimestre de 2015. Disponível em: www.univali.br/direitoepolitica - ISSN 19807791.

identificados com a ideia de fim estatal, afastando-se qualquer referência a uma materialidade pré-positiva ${ }^{21}$.

Para o autor, em razão da adaptação do Direito Penal à sociedade do risco, "o potencial descritivo da teoria do bem jurídico parece perder força", uma vez que " tradicional função minimalista de tutela de alguns bens previamente dados passa a dar lugar a uma função promocional, de garantia das gerações futuras (principalmente no tocante ao meio ambiente, à atividade econômica e à sanidade dos produtos distribuídos à população)", de maneira que a "ideia de que o Direito Penal serviria apenas à repressão e à proteção de bens jurídicos de titularidade direta do indivíduo estaria perdendo sua base concreta."22.

Nesse sentido, o Direito Penal "incorpora a função de instrumento de controle social, muito próximo, portanto, do direito administrativo, com o único diferencial na característica punitiva apresentada pelo primeiro"23. O Direito Penal administrativizado, assim, nega diversos princípios e garantias fundamentais essenciais desse ramo, como a intervenção mínima, pessoalidade, legalidade, a título de exemplo 24 .

Sobre o tema, Silva Sanchez anota que, com isso, "tem-se produzido certamente a culminação do processo: o Direito Penal, que reagia a posteriori contra um fato lesivo individualmente delimitado (quanto ao sujeito ativo e passivo)", acaba por se converter "em um direito de gestão (punitiva) de riscos gerais e, nessa medida, está "administrativizado". ${ }^{25}$

21 LUZ, Yuri Corrêa da. Entre bens jurídicos e deveres normativos: um estudo sobre os fundamentos do direito penal contemporâneo. 1.ed. - São Paulo: IBCCRIM, 2013, p. 85.

22 LUZ, Yuri Corrêa da. Entre bens jurídicos e deveres normativos: um estudo sobre os fundamentos do direito penal contemporâneo. 1.ed. - São Paulo: IBCCRIM, 2013, p. 81-82.

23 MACHADO, Édina Maria dos Santos. A administrativização do direito penal em face da sociedade do risco e a flexibilização dos princípios e garantias jurídico-penais. Revista de Ciências Jurídicas, Ponta Grossa, 4(1): 67-75, 2012, p. 69.

24 "Nesse contexto, esse setor do Direito estaria deixando de ser apenas um instrumento de reação contra violações a bens de titularidade do indivíduo, tornando-se, cada vez mais, um sistema de gestão e de alocação de grandes riscos". (LUZ, Yuri Corrêa da. Entre bens jurídicos e deveres normativos: um estudo sobre os fundamentos do direito penal contemporâneo. 1.ed. - São Paulo: IBCCRIM, 2013, . 79).

25 SILVA SÁNCHEZ, Jesús-María. A expansão do Direito Penal: aspectos da política criminal nas sociedades pós-industriais. São Paulo: Revista dos Tribunais, 2002, p. 114. 
SILVA, Lucas do Monte. O corrupto como inimigo no direito penal brasileiro. Revista Eletrônica Direito e Política, Programa de Pós-Graduação Stricto Sensu em Ciência Jurídica da UNIVALI, Itajaí, v.10, n.3, $2^{\circ}$ quadrimestre de 2015. Disponível em: www.univali.br/direitoepolitica - ISSN 19807791.

A celeuma repousa na razão da gestão punitiva dos referidos riscos serem feitas pelo ramo do Direito, pelos meios e métodos inadequados. ${ }^{26}$ Exemplo disso pode ser observado na utilização de bens jurídicos subjetivos, por meio de termos indeterminados, dificultando a aplicação de suas normas, bem como a eficácias destas $^{27}$.

Nos dizeres de Reale Júnior, a "administrativização do Direito Penal torna a lei penal um regulamento, sancionando a inobservância a regras de conveniência da administração pública, matérias antes de cunho disciplinar". O autor continua afirmando que no "seu substrato está a concepção pela qual a lei penal visa antes a 'organizar' do que a proteger, sendo, portanto, destituída da finalidade de consagrar valores e tutelá-los". ${ }^{28}$

Além disso, interpreta-se a administrativização do Direito Penal como um reflexo do seu próprio caráter expansivista das sociedades pós-modernas, como afirma Dias:

Dispõe-se, nesse contexto já de uma diversidade de propostas e ensaios de caminhos de solução que, todavia parecem poderem reconduzir-se às direcções que atrás ficaram referidas: alteração do modo próprio de produção legislativa em matéria penal, retirando cada vez mais aos parlamentos a reserva de competência que em tal matéria

26 Alves salienta que "hoje em dia, proliferam-se leis meramente simbólicas, cujos textos, muitas vezes, exorbitam, propositadamente, do emprego de expressões ambíguas e abertas. Conforme se torna mais complexa a sociedade, as novas condutas proibidas exsurgem, sem que necessariamente sejam revogados os preceitos obsoletos. O sistema penal inflaciona-se, porque - medo coletivo impele a criminalização". (ALVES, Fábio Wellington Ataíde. Efetivação da garantia de defesa no estado constitucional de direito: colisão entre poder punitivo e garantia de defesa. 2008. Dissertação (Mestrado)_ _ Universidade Federal do Rio Grande do Norte. p. 190).

27 Nesse sentido, salienta-se que "com o reconhecimento e aceitação dos riscos decorrentes das evoluções tecnológicas, naturalmente surge a tentativa de controlar esses riscos. $E$, com a crescente sensação de incerteza, emerge uma demanda social, especificamente normativa, por segurança." PERET ANTUNES, Leonardo L. . A expansão do direito penal na era da globalização e a criminalidade moderna. Tribuna Virtual IBCCRIM , v. 1, p. 54-72 , 2013, p. 57. Assim, "ao utilizar da tutela penal com o intuito de prevenir os riscos inerentes à vida moderna, o Estado inicia uma expansão, muitas vezes desnecessária e criticada, do Direito Penal. Hoje vivemos em um paradoxo, busca-se "menos Estado social, menos Estado interventor, mas mais Estado punitivo, mais Estado securitário". Em razão do aumento da sensação de insegurança provocada também pela criminalidade moderna, é disseminada a ideia de que apenas um Estado punitivo é apto a triunfar sobre esta criminalidade e, calcado nesta retórica, surgem aqueles que propõem a redução de direitos, liberdades e garantias fundamentais." (PERET ANTUNES, Leonardo L. . A expansão do direito penal na era da globalização e a criminalidade moderna. Tribuna Virtual IBCCRIM , v. 1, p. 54-72, 2013, p. 58)

${ }^{28}$ REALE JUNIOR, Miguel. Instituições de Direito Penal: parte geral. V. 1. Rio de Janeiro: Forense, 2004, p. 21. 
SILVA, Lucas do Monte. O corrupto como inimigo no direito penal brasileiro. Revista Eletrônica Direito e Política, Programa de Pós-Graduação Stricto Sensu em Ciência Jurídica da UNIVALI, Itajaí, v.10, n.3, $2^{\circ}$ quadrimestre de 2015. Disponível em: www.univali.br/direitoepolitica - ISSN 19807791.

normalmente the assiste, para atribuir aos Executivos; antecipação da tutela penal para estádios prévios (e inclusivamente ainda muito distanciados) da eventual lesão de um interesse socialmente significativo, até ao ponto em que se perde, ao menos para a generalidade dos destinatários das normas, toda a ligação entre a conduta individual e o bem jurídico que em definitivo se intenta em proteger; alterações dogmáticas básicas, no sentido de "enfraquecimento" ou "atenuação" de princípios como os que classicamente presidem à individualização da responsabilidade, à imputação objectiva, à culpa, à autoria; consequente extensão, em suma, do âmbito da tutela penal em assumida contradição com o princípio político criminal da intervenção mínima ou moderada ${ }^{29}$.

Essa questão pode ser vista de forma clara no caso da tutela do bem jurídico "moralidade administrativa". A Moralidade Administrativa é tutelada, desde 1992, pela Lei no 8.429, conhecida como Lei de Improbidade Administrativa, nos termos do disposto no art. 37, §4, da Constituição. Tal Lei divide os atos de improbidade em três categorias: os que causam enriquecimento ilícito (art. $9^{\circ}$ ), os que causam prejuízo ao erário (art. $10^{\circ}$ ) e os que atentam contra os princípios da Administração Pública (art. 110).

Frisa-se o dispositivo do art. 11, da Lei de Improbidade Administrativa, que informa que constitui ato de improbidade administrativa que atente "contra os princípios da administração pública qualquer ação ou omissão que viole os deveres de honestidade, imparcialidade, legalidade, e lealdade às instituições" (destaques acrescidos), e exemplifica, acentuando atos como: I - praticar ato visando fim proibido em lei ou regulamento ou diverso daquele previsto, na regra de competência; II - retardar ou deixar de praticar, indevidamente, ato de ofício; III - revelar fato ou circunstância de que tem ciência em razão das atribuições e que deva permanecer em segredo; IV - negar publicidade aos atos oficiais; V frustrar a licitude de concurso público; VI - deixar de prestar contas quando esteja obrigado a fazê-lo; VII - revelar ou permitir que chegue ao conhecimento de terceiro, antes da respectiva divulgação oficial, teor de medida política ou econômica capaz de afetar o preço de mercadoria, bem ou serviço.

${ }^{29}$ DIAS, Jorge de Figueiredo. Temas básicos da doutrina penal. Coimbra: Coimbra, 2001, p. 167168. 
SILVA, Lucas do Monte. O corrupto como inimigo no direito penal brasileiro. Revista Eletrônica Direito e Política, Programa de Pós-Graduação Stricto Sensu em Ciência Jurídica da UNIVALI, Itajaí, v.10, n.3, $2^{\circ}$ quadrimestre de 2015. Disponível em: www.univali.br/direitoepolitica - ISSN 19807791.

Merece destaque ressaltar que os procedimentos que se baseiam na referida Lei não se trata de processos criminais, mas sim, cíveis ou administrativos, buscando, assim, evitar a administrativização do Direito Penal. Sobreleva notar também as penas dispostas no art. 11 desta Lei de Improbidade Administrativa, que buscam a reparação do dano ao erário, em vez da punição apenas por punir. Entre elas, pode-se citar, independentemente das sanções penais, civis e administrativas previstas na legislação específica, que podem ser aplicadas, isolada ou cumulativamente, de acordo com a gravidade do fato, as penas de perda dos bens ou valores acrescidos ilicitamente ao patrimônio; ressarcimento integral do dano, quando houver; perda da função pública; suspensão dos direitos políticos por determinado prazo, a depender da conduta praticada; pagamento de multa civil multiplicado por diversas vezes o valor do acréscimo patrimonial, condicionada a gravidade do crime; proibição de contratar com o Poder Público ou receber benefícios ou incentivos fiscais ou creditícios, direta ou indiretamente, ainda que por intermédio de pessoa jurídica da qual seja sócio majoritário, pelo prazo de dez anos.

No entanto, cabe fazer três críticas quanto a supramencionada Lei.

Primeiro, merece crítica a abertura conceitual do ato de improbidade administrativa, possibilitando, pela interpretação de cada juiz, a adequação de determinada violação como ato atentatório contra os princípios da Administração. Em que pese não seja sempre de bom alvitre, do ponto da defesa social, delimitar as condutas e conceituar atos, uma vez que, dessa forma, estar-se-á excluindo condutas maléficas para a Administração Pública que, caso fosse adotado um conceito mais aberto, poderiam ser configuradas como atos de improbidade administrativa ${ }^{30}$; cabe salientar outro valor que possui guarida no ordenamento jurídico brasileira, a segurança jurídica (sem olvidar, por claro, os direitos e garantias fundamentais). Ora, a norma em apreço utiliza-se de termos vagos e indeterminados que, por fim, permitem que os juízes, à sua vontade, decidam o que seria um ato de improbidade administrativa ${ }^{31}$.

${ }^{30}$ Quanto à necessidade da descrição mais precisa da conduta, Cf. Roxin. Claus. Politica criminal y Sistema del derecho penal. 2. ed. Buenos Aires: Hammurabi, 2002. p. 19.

${ }^{31}$ Assim, Flores salienta "novos mecanismos e técnicas de tutela penal começam a ser utilizados como uma tentativa de gerenciar os riscos inerentes a essas atividades, bem como para dar vazão aos (inegáveis) interesses do Estado nas instâncias econômicas. Assim, torna-se muito 
SILVA, Lucas do Monte. O corrupto como inimigo no direito penal brasileiro. Revista Eletrônica Direito e Política, Programa de Pós-Graduação Stricto Sensu em Ciência Jurídica da UNIVALI, Itajaí, v.10, n.3, $2^{\circ}$ quadrimestre de 2015. Disponível em: www.univali.br/direitoepolitica - ISSN 19807791.

Segundo, quais são os princípios da Administração Pública? Seriam apenas os dispostos no art. 37, da Constituição da República, quais sejam, a legalidade, impessoalidade, moralidade, publicidade e eficiência? Ou outros novos princípios, que são inventados a todo momento, também adentram nesse conceito de princípios utilizado?. Nesse sentido, salienta-se a discussão de Lenio Streck quanto ao pan-principiologismo e o crescimento do ativismo judicial. Tendo por base valores neoconstitucionalistas, os julgadores utilizam-se de princípios constitucionais como álibis teóricos, para fugir da fundamentação de suas decisões; bem como arbitrariedade e discricionariedade judicial e, por extensão, do protagonismo judicial, visto que "a pretexto de superar o 'ultrapassado' silogismo e dedutivista do paradigma liberal-formal-burguês, vêm deslocando o locus do sentido do texto - que representa a produção democrática do direito na direção do protagonismo (racionalista-indutivista) do intérprete" ${ }^{\prime 32}$; dessa forma, há um pan-principiologismo, isto é, um excesso de princípios tautológicos, de modo que há uma "proliferação descontrolada de enunciados para resolver determinados problemas concretos, muitas vezes ao alvedrio da própria legalidade constitucional"33; e, por fim, do fomento a promoção da "cultura estandardizada", isto é, dos enunciados e das súmulas vinculantes que limitam a interpretação e o trabalho do jurista no processo de aplicação do direito.

Terceiro, o que seriam os deveres de honestidade, imparcialidade, legalidade e lealdade às instituições? Conforme visto alhures, sobretudo devido à diversidade cultural do Brasil, termos abertos, como os acima expostos, são vistos como pontos tênues, que cada sujeito cria, de maneira subjetiva, o seu próprio conceito. Semelhante ao que pode ser observado no estudo apresentado quanto

comum a utilização de leis penais em branco, crimes omissivos e de perigo abstrato, elementos normativos indeterminados e criação de posições artificiais de garante." (p. 37). O autor continua afirmando que a "excessiva generalidade na sua definição, ainda que possa ser considerada mais útil para abarcar casos não imaginados pelo legislador, viola o princípio da legalidade e todas as suas decorrências, os quais devem ser respeitados, pois garantias basilares do Estado Democrático de Direito". (MARCANTE FLORES, Marcelo. Crimes de colarinho branco e a formação do Direito Penal secundário: os desafios da política criminal contemporânea. Tribuna Virtual do IBCCRIM. Edição No. 5, 2013. p. 39.) Nesse sentido, também conferir DIAS, Jorge de Figueiredo. "O papel do direito penal na proteção das gerações futuras." Boletim da Faculdade de Direito da Universidade de Coimbra-volume comemorativo do $75^{\circ}$ Volume, Coimbra (2003): 1123-1138.

32 STRECK, Lênio. L. Hermenêutica Jurídica e $(m)$ Crise. 10.ed. Porto Alegre: Livraria do Advogado, 2011. p. 44.

${ }^{33}$ STRECK, Lênio. L. Hermenêutica Jurídica e $(m)$ Crise. 10.ed. Porto Alegre: Livraria do Advogado, 2011. p. 50. 
SILVA, Lucas do Monte. O corrupto como inimigo no direito penal brasileiro. Revista Eletrônica Direito e Política, Programa de Pós-Graduação Stricto Sensu em Ciência Jurídica da UNIVALI, Itajaí, v.10, n.3, $2^{\circ}$ quadrimestre de 2015. Disponível em: www.univali.br/direitoepolitica - ISSN 19807791.

à diferença entre a corrupção e o "jeitinho brasileiro", também não há unanimidade quanto aos conceitos de honestidade e lealdade. Imagine-se um acadêmico de Direito que estuda em uma Universidade Pública Federal, "colando" as respostas de uma prova do seu colega, ou, por exemplo, em vez de fazer o trabalho acadêmico solicitado pelo seu professor, o mesmo aluno resolve "copiar e colar", isto é, praticar plágio, copiando ideias de outro autor e entregálo como se suas fossem. Este aluno estaria praticando uma conduta contrária à honestidade e lealdade à instituição pública na qual estuda? Em que pese o aluno não possa ser punido com base na lei vertente, tendo em vista não ser um agente público, pode-se observar a amplitude dos termos utilizados que são, ainda mais, ampliados, com a forma livre da conduta, permitindo que qualquer ação ou omissão possa configurar como um ato de improbidade administrativa, dependendo da livre vontade do julgador.

Observa-se, diante da Sociedade de Riscos e da macrocriminalidade, a tenuidade de determinados conceitos e, consequentemente, dos delitos que utilizam essas expressões, de maneira a ocasionar a perda de segurança jurídica, em diversas demandas apresentadas ao Judiciário. Não obstante, não se pode olvidar a existência de violações diárias aos direitos e garantias fundamentais, com interpretações à margem da lei, que não são postas em destaque, a não ser que se trata de casos envolvendo grandes políticos ou empresários ${ }^{34}$.

\section{O CORRUPTO É UM INIMIGO NO DIREITO PENAL BRASILEIRO?}

Não é incomum a divisão pelo senso comum midiático das pessoas entre "homens de bem", "honestos" e "trabalhadores" e os "marginais", "corruptos". Os "homens de bem" são aqueles que, em tese, cumprem seus deveres, diante do Estado e dos seus semelhantes. Os marginais e corruptos, por sua vez, não

34 Bizarria, citando Greco, anota que o "Direito Penal objetiva tutelar bens que, por serem extremamente valiosos, não só do ponto de vista econômico, mas também político, não podem ser protegidos de maneira satisfatória pelos demais ramos do Direito, "de forma que, com a adoção do Direito Penal do Inimigo tem-se que o "Direito Penal serviria como um instrumento público a serviço do Estado e não como uma medida de ultima ratio voltada para a proteção dos Direitos Humanos." (BIZARRIA, Breno Timbó Magalhães. O direito penal do inimigo aplicado a um estado democrático de direito. Revista Acadêmica da Escola Superior do Ministério Público do Estado do Ceará. Fortaleza, ano 4. n.2 ago./dez. 2012.p. 5) 
SILVA, Lucas do Monte. O corrupto como inimigo no direito penal brasileiro. Revista Eletrônica Direito e Política, Programa de Pós-Graduação Stricto Sensu em Ciência Jurídica da UNIVALI, Itajaí, v.10, n.3, $2^{\circ}$ quadrimestre de 2015. Disponível em: www.univali.br/direitoepolitica - ISSN 19807791.

respeitam o "contrato social" e voltam-se à prática de crimes e contravenções penais, atingindo e violando os bens jurídicos tutelados pelo Direito Penal. ${ }^{35}$ Tais marginais acabam por se tornar inimigos dos "homens de bem".

Ocorre que a sociedade, em razão do discurso do senso comum midiático, com fortes traços da ideologia da defesa social (sobretudo princípio do bem e do mal, que se baseia na necessidade de controle da criminalidade, que representa o "mal", sendo uma ação disfuncional e negativa para o sistema penal em prol da sociedade, que representa o "bem"), define os "homens de bem" em uma ideia frágil de uma "pessoa honesta e trabalhadora", mas sem considerar que, diariamente, estes praticam infrações penais, mesmo sem, à primeira vista, terem qualquer intenção nesse sentido.

Santos Júnior, buscando exemplificar essa situação, apresenta cinco hipotéticas para que seja possível verificar se você, o leitor, a priori, poderia, efetivamente, ser considerado um "homem de bem". Primeira, você já comprou produtos made in Paraguai? "Se comprou, voce acaba de se assumir receptador, tendo infringido a regra do artigo 180 do Código Penal (pena de 1 a 4 anos de reclusão, e multa)". Segunda, já deu ou tentou dar "bola" ao guarda de transito, isto é, fornecer uma certa quantia de dinheiro para que este não o multe? Nesse caso, você se torna um "corruptor ativo (art. 333 do CP: 2 a 12 anos de reclusão, e multa)". Terceira, já comprou algum produto ou serviço "sem nota fiscal" para reduzir o seu preço? Caso você já tenha feito isso, você é "o infrator da Lei $8.137 / 90$ (art. $1^{\circ}$, inciso II: pena de reclusão de 2 a 5 anos e multa". Quarta, já dirigiu alguma vez sob o efeito de álcool e causou risco a alguém? "Se assim o fez, infringiu a regra do artigo 306 do Código de Trânsito Brasileiro (pena de detenção de 6 meses a 3 anos, multa e suspensão ou proibição de obter a permissão ou habilitação para dirigir)". Quinta, já levou "loló" ou lança-perfume para o carnaval/micareta e dividiu com amigos? Pois bem, você pode ser considerado um "traficante, pois você violou a norma do art. 12 da Lei 6.368/76,

\footnotetext{
35 SANTOS JÚNIOR, Rosivaldo Toscano dos. Discurso sobre e o sistema penal - uma visão crítica.
} Revista Direito e Liberdade. v. 3, n. 2, p. 629 - 654 - set 2006, p. 632. 
SILVA, Lucas do Monte. O corrupto como inimigo no direito penal brasileiro. Revista Eletrônica Direito e Política, Programa de Pós-Graduação Stricto Sensu em Ciência Jurídica da UNIVALI, Itajaí, v.10, n.3, $2^{\circ}$ quadrimestre de 2015. Disponível em: www.univali.br/direitoepolitica - ISSN 19807791.

delito cuja pena vai de 3 a 15 anos de reclusão, e multa, além da equiparação a crime hediondo"36.

Trata-se de situações cotidianas que pela aceitação social não ensejam na criação da imagem do "inimigo" nessas pessoas. Ao revés, em diversos casos são incentivadas, de forma que as pessoas que não seguem esse padrão tornam-se motivo de chacota. Ora, para que comprar um DVD original em uma loja, se você pode comprá-lo por menos do que cinco reais no centro da cidade? Por que você vai pagar o preço inteiro do produto, se a loja te dará $10 \%$ de desconto, caso você não solicite a nota fiscal? Por qual motivo você não irá voltar para casa no seu próprio carro, se você bebeu apenas duas latas de bebida alcoólica? Por que não levar o "loló" e a "maconha" para o carnaval, se se trata de um momento de festa em que todos se divertem?

São com essas perguntas que os pretensos "homens de bem" justificam suas condutas contrárias ao ordenamento jurídico brasileiro. A pessoa que compra o DVD original na loja, solicita a nota fiscal do produto ou serviço que adquiriu, volta para casa de carona ou de táxi, não utiliza qualquer tipo de droga ilegal, é aquela que, paradoxalmente, é excluída da sociedade (como seres diferentes/estranhos) pelos "homens de bem".

Com efeito, os "homens de bem", que se utilizam, em seus discursos midiáticos, baseados na ideologia da defesa social, de expressões comumente relacionados ao trabalhador honesto, de lisura, contrários a qualquer tipo de aversão à ordem jurídica, sob a óptica estritamente jurídica, deveriam se tornar "marginais" e "inimigos" da sociedade, o que não ocorre, pois, assim, se estaria a desconstruir o principal argumento dessa corrente.

Pois bem, desconstruído o conceito de "homem de bem" utilizado sobremaneira em discursos do senso comum midiático contra a corrupção no Brasil, cabe analisar os fundamentos nos quais repousam os motivos da reprovação do crime econômico (vide corrupção), unidos a concepção de crime de colarinho branco,

\footnotetext{
36 SANTOS JÚNIOR, Rosivaldo Toscano dos. Discurso sobre e o sistema penal - uma visão crítica. Revista Direito e Liberdade. v. 3, n. 2, p. 629 - 654 - set 2006, p. 632
} 
SILVA, Lucas do Monte. O corrupto como inimigo no direito penal brasileiro. Revista Eletrônica Direito e Política, Programa de Pós-Graduação Stricto Sensu em Ciência Jurídica da UNIVALI, Itajaí, v.10, n.3, $2^{\circ}$ quadrimestre de 2015. Disponível em: www.univali.br/direitoepolitica - ISSN 19807791.

de forma a tornar possível verificar se o sujeito ativo desse crime pode ser considerado um inimigo ${ }^{37}$.

O conceito de crime de colarinho branco (white collar crime) teve origem nos EUA, em 1940, notadamente devido aos estudos de Sutherland. O autor observou, diante do crescimento geográfico e demográfico desordenado que ocorreu em Chicago, que o local se tornou um ambiente propício para o desenvolvimento da máfia americana. Ademais, observou que existia uma diferença entre os crimes capitaneados pela máfia, isto é, pelos donos do poder na cidade e a criminalidade comum (qual seja, crimes praticados por pessoas de baixa renda com pouca educação, que não tiveram oportunidades suficientes na vida $)^{38}$. Assim, o referido autor dissocia os pressupostos criminológicos tradicionais positivistas da etiologia, que via o crime como uma "herança biologia", isto é, a relação causal entre o crime e os fatores psicossociais; em prol da visão do crime como resultado de uma aprendizagem, isto é, como resultado das influências favoráveis à infração no que contexto em que o sujeito sobrevive. ${ }^{39}$

Para essa teoria, "a motivação para a prática do crime e o conhecimento dos procedimentos para cometê-lo são apreendidos mediante processos comunicativos que ocorrem no interior dos grupos sociais", ou seja, "quando valores dominantes no seio do grupo forem propícios ao cometimento de

\footnotetext{
37 "Diante disso, principalmente a partir da incorporação dos direitos e interesses coletivos e difusos pelo sistema jurídico-penal, a concepção de bem jurídico assume extrema relevância. Sobretudo, quando se fala em política criminal e criação de novos tipos penais, pois devem ser respeitados critérios de precisão e certeza, os quais possuem especial relevância para se garantir um mínimo de segurança jurídica por meio do princípio da legalidade, em um Estado Democrático de Direito. (p. 34)". Para Flores, as "reflexões sobre o crime de colarinho branco anteciparam o que veio a ser depois afirmado pelos teóricos do labelling approach, ao considerar que uma conduta se torna criminosa quando é assim definida pela sociedade por meio do sistema democrático, o qual está sujeito aos (poderosos) grupos de pressão. (p. 28) (MARCANTE FLORES, Marcelo. Crimes de colarinho branco e a formação do Direito Penal secundário: os desafios da política criminal contemporânea. Tribuna Virtual do IBCCRIM. Edição No. 5, 2013.).

38 SUTHERLAND, Edwin H. White Collar Criminality. American Sociological Review. 1940;5:1-12, p. 1.

39 Sutherland, então, desenvolveu seu trabalho científico "considerando este outro tipo de criminalidade, que se diferenciava da criminalidade comum (geralmente crimes praticados por pessoas de baixa renda e pouca instrução, não inseridas nas camadas sociais mais elevadas). Para o sociólogo, o crime é resultado de aprendizagem e não de uma "herança biológica", como pressupunham as teorias criminológicas de sua época". (ANTUNES, Leonardo Leal Peret. A expansão do direito penal na era da globalização e a criminalidade moderna. Tribuna Virtual do IBCCRIM. v. 1, p. 54-72, 2013, p. 61.)
} 
SILVA, Lucas do Monte. O corrupto como inimigo no direito penal brasileiro. Revista Eletrônica Direito e Política, Programa de Pós-Graduação Stricto Sensu em Ciência Jurídica da UNIVALI, Itajaí, v.10, n.3, $2^{\circ}$ quadrimestre de 2015. Disponível em: www.univali.br/direitoepolitica - ISSN 19807791.

infrações, o indivíduo violará a lei, precisamente porque os estímulos favoráveis a tal comportamento excedem os desfavoráveis" ${ }^{\prime 40} .41$

É, nesse sentido, que Sutherland elabora a teoria da "differential association", constatando "quer a motivação para a prática de um crime, quer o conhecimento dos procedimentos para o cometer são apreendidos através de processos de comunicação no interior do grupo", de maneira que "o crime pode ser cometido por pessoas absolutamente normais, que apenas receberam a influência de padrões favoráveis à infracção". ${ }^{42}$

Com isso, o autor define, por meio de uma conotação subjetiva, o crime de colarinho branco como aquele cometido por pessoas com privilégios sociais, originados de uma classe superior ("a violation of criminal law by a person of the upper socio-economic class in the course of his occupation activities".). Entre os elementos desse tipo de crime, citam-se: (i) a existência de um crime; (ii) cometido por pessoa "respeitável"; (iii) com elevado status social; (iv) no exercício de sua profissão; e (v) ocorrendo, em regra, uma violação de confiança; v) a opacidade, a dificuldade de sancionar a prática das infrações, a não violência dos agentes criminosos, a aparente inexistência (difusão) de vítimas e a dispersão da responsabilidade ${ }^{43}$.

Em que pese os crimes de colarinho branco possam ser diferenciados do conceito de "crime organizado", conforme pode ser observado nas seções iniciais do presente artigo, no cenário brasileiro, os dois, em regra, se confundem. A corrupção é sistematizada, sendo um verdadeiro crime organizado. Segundo Alberto Silva Franco, entre as características do crime organizado podem-se destacar: (i) caráter transnacional; (ii) imenso poder; (iii) danosidade social de

40 MARCANTE FLORES, Marcelo. Crimes de colarinho branco e a formação do Direito Penal secundário: os desafios da política criminal contemporânea. Tribuna Virtual do IBCCRIM. Edição No. 5, 2013, p. 26.

41 "The hypothesis which is here suggested as a substitute for the conventional theories is that white-collar criminality, just as other systematic criminality, is learned; that it is learned in direct or indirect association with those who already practice the behavior; and that those who learn this criminal behavior are segregated from frequent and intimate contacts with law-abiding behavior."(SUTHERLAND, Edwin H. White Collar Criminality. American Sociological Review. $1940 ; 5: 1-12$, p. 11)

42 ANTUNES, Leonardo Leal Peret. A expansão do direito penal na era da globalização e a criminalidade moderna. Tribuna Virtual do IBCCRIM. v. 1, p. 54-72, 2013, p. 61

43 ANTUNES, Leonardo Leal Peret. A expansão do direito penal na era da globalização e a criminalidade moderna. Tribuna Virtual do IBCCRIM. v. 1, p. 54-72, 2013, p. 63 
SILVA, Lucas do Monte. O corrupto como inimigo no direito penal brasileiro. Revista Eletrônica Direito e Política, Programa de Pós-Graduação Stricto Sensu em Ciência Jurídica da UNIVALI, Itajaí, v.10, n.3, $2^{\circ}$ quadrimestre de 2015. Disponível em: www.univali.br/direitoepolitica - ISSN 19807791.

grande vulto; (iv) grande força de expansão, compreendendo uma gama de condutas infracionais sem vítimas ou com vítimas difusas; (v) meios instrumentais de moderna tecnologia; (vi) conexão com outras organizações criminosas e oficiais da vida social, econômica e política; (vii) atos de extrema violência; e (viii) poder de corrupção e capacidade de inerciar ou fragilizar o Estado. $^{44}$

O caso Lava Jato adequa-se perfeitamente nos conceitos acima expostos. Primeiramente, de acordo com a tese do Ministério Público Federal (MPF), os delitos foram executados por pessoas com privilégios sociais, originados de uma classe superior, quais sejam, políticos e executivos de alto escalão das empreiteiras e de empresas estatais. Segundo, observa-se o caráter transnacional com a utilização de bancos estrangeiros. Terceiro, o imenso poder, com a violação de princípios constitucionais, nas licitações da maior estatal do País, Petrobras. Quarto, a danosidade social de grande vulto e o potencial de expansão, com os prejuízos, calculados pelo MPF e pela Polícia Federal (PF) em R\$10 bilhões. Quinto, o poder de corrupção e capacidade de inerciar ou fragilizar - Estado, pela própria violação a moralidade administrativa, valor essencial para a Administração Pública ${ }^{45}$.

Nota-se, assim, que as questões que aqui estão sendo expostas não possuem importância apenas teórica, mas também pragmática, sobretudo diante do aumento de casos de corrupção que vêm sendo vislumbrados. ${ }^{46}$

44 ANTUNES, Leonardo Leal Peret. A expansão do direito penal na era da globalização e a criminalidade moderna. Tribuna Virtual do IBCCRIM. v. 1, p. 54-72, 2013, p. 64

45 BRASIL. MINISTÉRIO PÚBLICO FEDERAL. Caso Lava Jato. Disponível em: <http://www.lavajato.mpf.mp.br>. Acesso em: 30 mar. 2015.

46 Tais se crime dirigem "contra interesses coletivos e supraindividuais da vida econômica. O bem protegido, portanto, não é o interesse individual dos agentes econômicos, senão o (bom) desenvolvimento da economia estatal no seu conjunto" (p. 35), de forma que as "categorias normativas nas quais os penalistas, até os dias de hoje, acostumaram-se a trabalhar parecem não mais servir. É preciso repensá-las também pela necessidade de se refletir sobre a noção normativa de espaço ilimitado ou global. Basta pensar na criminalidade econômica levada a cabo por meios informáticos, nos quais o lugar da prática do fato pode não ter qualquer relação com o resultado." (p. 37). Por fim, destaca-se que o "crime por excelência na era global é o crime econômico. É o multiplicar, em termos inéditos, tanto da criminalidade econômica como da delinqüência de colarinho branco, como ainda e por último, dos crimes of powerful em larga escala, de circuitos criminosos que englobam a circulação de grandes capitais e a movimentação de inúmeras pessoas e organizações, frequentemente à escala internacional ou global, em prol de um fim comum, a obtenção de lucros fabulosos provenientes da prática criminosa." (MARCANTE FLORES, Marcelo. Crimes de colarinho branco e a formação do Direito 
SILVA, Lucas do Monte. O corrupto como inimigo no direito penal brasileiro. Revista Eletrônica Direito e Política, Programa de Pós-Graduação Stricto Sensu em Ciência Jurídica da UNIVALI, Itajaí, v.10, n.3, $2^{\circ}$ quadrimestre de 2015. Disponível em: www.univali.br/direitoepolitica - ISSN 19807791.

Pois bem, feitas as considerações sobre esses tipos de crime econômico, cabe, por oportuno, analisar o que poderia ser considerado um "inimigo" para a Ciência Criminal.

Segundo Jakobs, são inimigos os "criminosos econômicos, terroristas, delinquentes organizados, autores de delitos sexuais e outras infrações penais perigosas" ${ }^{\prime 47}$, isto é, aqueles sujeitos que se afastam de forma permanente da ordem jurídica, sem garantir que irão respeitar os valores e as normas da sociedade, de forma que se torna necessária a aplicação antecipada de pena como segurança para impedir fatos futuros, com função de neutralização da periculosidade do autor, segundo a teoria das medidas de segurança. ${ }^{48}$

Como os altos índices de violência e impunidade, a população seguindo o discurso do senso comum midiático, aclama pela expansão do Direito Penal ${ }^{49}$ e de penas mais cruéis, por vezes, ilegais, aos transgressores da lei penal ${ }^{50}$. É, nesse contexto, que o Direito Penal do Inimigo ganha força. Neste, cria-se um subramo no Direito Penal, com a "intenção de proporcionar maiores poderes ao Estado no combate à criminalidade, gerando uma repressão intensa ao indivíduo que se afasta do ordenamento, o qual será tratado de forma adversa do cidadão comum, sendo supridos alguns direitos e garantias em favor do "bem-estar

Penal secundário: os desafios da política criminal contemporânea. Tribuna Virtual do IBCCRIM. Edição No. 5, 2013.)

47 JAKOBS, Günther e MELIÁ Mauel Cancio. Direito Penal do Inimigo: Noç̃oes e Críticas. 6. ed. Porto Alegre: Livraria do Advogado Editora, 2012.

48 SANTOS, Juarez Cirino do. O direito penal do inimigo - ou o discurso do direito penal desigual. Disponível em: <http://www.cirino.com.br/artigos/jcs/Direito\%20penal\%20do\%20inimigo.pdf>. Acesso em: 25 mar. 2015. p. 8

${ }^{49}$ Nesse sentido, abre-se azo para o crescimento do "assim, portanto, haverá de ser entendida a expressão "direito penal simbólico", como sendo o conjunto de normas penais elaboradas no clamor da opinião pública, suscitadas geralmente na ocorrência de crimes violentos ou não, envolvendo pessoas famosas no Brasil, com grande repercussão na mídia, dada a atenção para casos determinados, específicos e escolhidos sob o critério exclusivo dos operadores da comunicação, objetivando escamotear as causas históricas, sociais e políticas da criminalidade, apresentando como única resposta para a segurança da sociedade a criação de novos e mais rigorosos comandos normativos penais". (PRAZERES, José de Ribamar Sanches. O Direito Penal Simbólico Brasileiro. Disponível em: <www.sedep.com.br/?idcanal=24849>. Acesso em: 23 mar. 2015)

50 BIZARRIA, Breno Timbó Magalhães. O direito penal do inimigo aplicado a um estado democrático de direito. Revista Acadêmica da Escola Superior do Ministério Público do Estado do Ceará. Fortaleza, ano 4. n.2 ago./dez. 2012, p.1 
SILVA, Lucas do Monte. O corrupto como inimigo no direito penal brasileiro. Revista Eletrônica Direito e Política, Programa de Pós-Graduação Stricto Sensu em Ciência Jurídica da UNIVALI, Itajaí, v.10, n.3, $2^{\circ}$ quadrimestre de 2015. Disponível em: www.univali.br/direitoepolitica - ISSN 19807791.

social" $^{\prime 21}$. Trata-se de um Direito Penal rigoroso direcionado especificamente aos crimes mais graves, em razão de sua periculosidade, de maneira que merecem um tratamento diferenciado pela norma penal.

O Direito Penal do inimigo divide a sociedade entre "cidadãos" e "inimigos". Os cidadãos são as pessoas comuns que respeitam a ordem jurídica, atendendo as expectativas normativas vigentes, que mesmo que venham a delinquir, poderão ser reeducados. Os inimigos, por sua vez, são pessoas contrárias à sociedade e ao Direito, que demonstram o seu déficit cognitivo, pelas práticas delituosas, que não poderão ser reintegrados à sociedade e as suas normas regentes, de forma que ameaçam a própria existência do Estado. No inimigo, enxerga-se uma "fonte de perigo para os bens a serem protegidos, alguém que não dispõe de qualquer esfera privada, mas que pode ser responsabilizado até mesmo por seus mais íntimos pensamentos" ${ }^{\prime \prime 2}$.

Assim, o inimigo é o "autor de crimes de alta traição, que assume uma atitude de insubordinação jurídica intrínseca, uma base subjetiva real capaz de produzir um estado de guerra contra a sociedade", que, de forma permanente, frustra as "expectativas normativas da comunidade, perdendo a qualidade de pessoa portadora de direitos, porque desafia o sistema social."53. Este seria "uma personalidade criminógena definível como adversário de princípio da organização de poder social, incapaz de um modus vivendi comum (contradição inimigo/sociedade). 5455

${ }^{51}$ BIZARRIA, Breno Timbó Magalhães. O direito penal do inimigo aplicado a um estado democrático de direito. Revista Acadêmica da Escola Superior do Ministério Público do Estado do Ceará. Fortaleza, ano 4. n.2 ago./dez. 2012, p. 3

52 GRECO, Luís. Sobre o chamado Direito Penal do Inimigo. Revista da Faculdade de Direito de Campos, Ano VI, No 7 - Dezembro de 2005. p. 214.

53 SANTOS, Juarez Cirino do. O direito penal do inimigo - ou o discurso do direito penal desigual. Disponível em: <http://www.cirino.com.br/artigos/jcs/Direito\%20penal\%20do\%20inimigo.pdf>. Acesso em: 25 mar. 2015, p. 5

54 SANTOS, Juarez Cirino do. O direito penal do inimigo - ou o discurso do direito penal desigual. Disponível em: <http://www.cirino.com.br/artigos/jcs/Direito\%20penal\%20do\%20inimigo.pdf>. Acesso em: 25 mar. 2015, p. 6

55 "O dito direito penal do inimigo tem foco no futuro, ou seja, o chamado inimigo é punido pelo delito que possa vir a cometer futuramente e não pelo ilícito já cometido; é uma espécie de prevenção à prática de novos crimes."(SOUZA, Paulo de Andrade e. O Direito Penal do Inimigo e o Garantismo Penal. Escola da Magistratura do Estado do Rio de Janeiro. 2012. Disponível em: http://www.emerj.tjrj.jus.br/paginas/trabalhos_conclusao/1semestre2012/trabalhos_12012/paul aandradesouza.pdf >. Acesso em: 26 mar. 2015, p. 7) 
SILVA, Lucas do Monte. O corrupto como inimigo no direito penal brasileiro. Revista Eletrônica Direito e Política, Programa de Pós-Graduação Stricto Sensu em Ciência Jurídica da UNIVALI, Itajaí, v.10, n.3, $2^{\circ}$ quadrimestre de 2015. Disponível em: www.univali.br/direitoepolitica - ISSN 19807791.

Nesse sentido, o "fim maior do Direito Penal do Inimigo é a segurança cognitiva. A sociedade, uma vez consciente dos riscos, passa a ter necessidade de sobrepesar a antijuridicidade e a efetividade das normas". Assim, para Jakobs, a "imposição de penas deve ter caráter eminentemente preventivo. Fato típico, à vista disso, não se configuraria como lesão a bens jurídicos, mas como lesão à própria juridicidade" ${ }^{56}$. Nesse sentido, o autor

(...) revela - quiça inconscientemente - o seu verdadeiro propósito, que é legitimar um direito penal de guerra, um direito penal que adota uma postura belicosa, de combate, de eliminação, de destruição do próximo para manter estável uma ordem dada. Em resumo, de destruição do humano em prol da preservação da ordem jurídica (MUÑOZ CODE; BUSATO, 2011, p.192) $)^{57}$

No Direito Penal do Inimigo, conforme salienta Cancio Meliá, há um verdadeiro Direito Penal do autor, no qual o agente é punido pela sua identidade, por suas características e sua personalidade. Pune-se o autor, e não, a conduta em si. Assim, reprova-se a periculosidade do agente e não sua culpabilidade. ${ }^{58}$

O Direito Penal da "sociedad civil sufre una transformación que lo convierte en un 'Derecho penal del enemigo'; la 'modernidad' social institucionaliza bajo el eslógan de la 'seguridad interior' un 'estado de excepción' político como estándar jurídico-penal." 59 . Neste direito penal dos riscos, adotam-se "características antiliberales: en la regulación jurídica de la persecución penal y en el proceso

${ }^{56}$ BIZARRIA, Breno Timbó Magalhães. O direito penal do inimigo aplicado a um estado democrático de direito. Revista Acadêmica da Escola Superior do Ministério Público do Estado do Ceará. Fortaleza, ano 4. n.2 ago./dez. 2012. p. 7.

${ }^{57}$ BIZARRIA, Breno Timbó Magalhães. O direito penal do inimigo aplicado a um estado democrático de direito. Revista Acadêmica da Escola Superior do Ministério Público do Estado do Ceará. Fortaleza, ano 4. n.2 ago./dez. 2012.

${ }^{58}$ BIZARRIA, Breno Timbó Magalhães. O direito penal do inimigo aplicado a um estado democrático de direito. Revista Acadêmica da Escola Superior do Ministério Público do Estado do Ceará. Fortaleza, ano 4. n.2 ago./dez. 2012, p. 8-9.

59 MÜSSIG, Bernd. Desmaterialización del bien jurídico y de la política criminal: sobre las perspectivas y los fundamentos de uma teoría del bien jurídico crítica hacia el sistema. Tradução de Manuel Cancio Meliá e Enrique Peñaranda Ramos. Colombia: Universidad Externado de Colombia, 2001. p. 170 
SILVA, Lucas do Monte. O corrupto como inimigo no direito penal brasileiro. Revista Eletrônica Direito e Política, Programa de Pós-Graduação Stricto Sensu em Ciência Jurídica da UNIVALI, Itajaí, v.10, n.3, $2^{\circ}$ quadrimestre de 2015. Disponível em: www.univali.br/direitoepolitica - ISSN 19807791.

penal propiamente dicho se sacrifican garantías de libertad fundamentales en el altar de una pretendida lucha efectiva contra la criminalidad". 60

Com o discurso do estado de exceção, flexibilizam-se as garantais e direitos fundamentais, e o sistema processual penal cinde-se "entre a imputação fundada no princípio acusatório para o cidadão, acusado com as garantias constitucionais do processo legal devido (ampla defesa, presunção de inocência etc.)", por um lado, e, em outro, "a imputação fundada no princípio inquisitório para o inimigo, punido sem as garantias constitucionais do processo legal devido (defesa restrita, presunção de culpa etc.), com investigações ou inquéritos secretos, vigilâncias sigilosas, interceptação telefônica, escuta ambiental, prisões temporárias, proibição de contato com advogado etc ${ }^{\prime 161}$. Dessa forma, o processo contra o inimigo não tem mais uma forma de justiça, mas sim, de guerra, mesmo que atinja terceiros inocentes. ${ }^{62}$

O inimigo como inimigo que é, não possui nenhuma garantia constitucional, de forma que, para combater o perigo, o Estado pode se valer de medidas radicais $^{63}$, em muitos casos ilegais e inconstitucionais, para diminuir as garantias constitucionais, fazendo aumentos desproporcionais de penas, antecipando a tutela penal etc. ${ }^{64}$ Nesse sentido, Souza salienta que:

60 MÜSSIG, Bernd. Desmaterialización del bien jurídico y de la política criminal: sobre las perspectivas y los fundamentos de uma teoría del bien jurídico crítica hacia el sistema. Tradução de Manuel Cancio Meliá e Enrique Peñaranda Ramos. Colombia: Universidad Externado de Colombia, 2001. p. 170.

61 SANTOS, Juarez Cirino do. O direito penal do inimigo - ou o discurso do direito penal desigual. Disponível em: <http://www.cirino.com.br/artigos/jcs/Direito\%20penal\%20do\%20inimigo.pdf>. Acesso em: 25 mar. 2015. p. 11.

62 É, nesses casos, que deve-se ter cautela como os "motivos invocados, com freqüência, pelas Primeira e Segundas Instâncias, que se encerram em fórmulas como o clamor público provocado pelo crime, em decorrência de sua gravidade concreta ou abstrata, a necessidade de preservar a credibilidade das instituições judiciárias ou o bem jurídico pela norma incriminadora, pois, em nenhuma delas, é possível visualizar embaraços ao resultado útil do processo, criados pelo paciente ou por alguém em seu favor." (Habeas Corpus 95.009-4 SP. Rel. Min. Eros Grau.)

63 Salienta-se relevante voto do Min. Eros Grau, no qual afirma que "ao abrir mão das garantias mínimas do Estado de direito, o que poderíamos chamar de a nossa sociedade civil submete-se a um estado de exceção permanente, prescindindo de qualquer déspota que a oprima." (Habeas Corpus 95.009-4 SP. Rel. Min. Eros Grau.)

64 SOUZA, Paulo de Andrade e. O Direito Penal do Inimigo e o Garantismo Penal. Escola da Magistratura do Estado do Rio de Janeiro. 2012. Disponível em: http://www.emerj.tjrj.jus.br/paginas/trabalhos_conclusao/1semestre2012/trabalhos_12012/paul aandradesouza.pdf>. Acesso em: 26 mar. 3015, p. 9 
SILVA, Lucas do Monte. O corrupto como inimigo no direito penal brasileiro. Revista Eletrônica Direito e Política, Programa de Pós-Graduação Stricto Sensu em Ciência Jurídica da UNIVALI, Itajaí, v.10, n.3, $2^{\circ}$ quadrimestre de 2015. Disponível em: www.univali.br/direitoepolitica - ISSN 19807791.

Como o inimigo de Jakobs é uma "não pessoa", a qual o
Estado visa combater, neutralizar, e livrar a sociedade de
todo o mal que este possa causar, a ele não são previstos os
direitos e garantias processuais a que os cidadãos têm
direito, motivo pelo qual o inimigo não em excesso pode ser
tratado como sujeito processual, pois "com seus instintos e
medos põem em perigo a tramitação ordenada do processo"
65

Ocorre que as "as garantias fundamentais passam a ser vistas como um 'entrave' a ser transposto no momento da criação dos novos tipos penais e aplicação do direito no caso concreto" ${ }^{\prime \prime 6}$.

Afinal, postas essas considerações, torna-se necessário responder ao questionamento-objetivo do presente artigo: O corrupto é um inimigo no Direito Penal brasileiro? A resposta é positiva. Em razão da política criminal (partindo do pressuposto de que o Brasil possui uma política criminal) adotada pelo Brasil, nas últimas décadas, o Direito Penal foi sendo ajustado para punir de forma cada vez mais severa a corrupção. No entanto, cabe ressaltar que essa resposta é positiva para o Direito Penal e para a Política Criminal, mas não para Criminologia, um dos ramos autônomos da Ciência Criminal.

Nesse sentido, a título de exemplo, pode-se trazer à tona a discussão das "10 Medidas contra a corrupção" apresentadas pelo Ministério Público Federal, que mostram nítidos traços da criação da imagem do inimigo, por meio da diminuição de garantias constitucionais. Entre estas, pode-se citar: i) Aumentar penas para casos de corrupção; ii) Tornar crime hediondo a corrupção de altos valores; iii) Mudar as regras de apresentação de contrarrazões em segunda instância, revogação dos embargos infringentes, extinção da revisão do voto do relator no julgamento da apelação, mudança nas regras de embargos de declaração, do recurso extraordinário e do habeas corpus em diversos dispositivos; iv) Possibilitar a execução provisória da pena após o julgamento na instância superior.; v) Restringir as nulidades processuais a casos em que são

65 SOUZA, Paulo de Andrade e. O Direito Penal do Inimigo e o Garantismo Penal. Escola da Magistratura do Estado do Rio de Janeiro. 2012. Disponível em: http://www.emerj.tjrj.jus.br/paginas/trabalhos_conclusao/1semestre2012/trabalhos_12012/paul aandradesouza.pdf>. Acesso em: 26 mar. 3015, p. 10

66 MARCANTE FLORES, Marcelo. Crimes de colarinho branco e a formação do Direito Penal secundário: os desafios da política criminal contemporânea. Tribuna Virtual do IBCCRIM. Edição No. 5, 2013, p. 40. 
SILVA, Lucas do Monte. O corrupto como inimigo no direito penal brasileiro. Revista Eletrônica Direito e Política, Programa de Pós-Graduação Stricto Sensu em Ciência Jurídica da UNIVALI, Itajaí, v.10, n.3, $2^{\circ}$ quadrimestre de 2015. Disponível em: www.univali.br/direitoepolitica - ISSN 19807791.

necessários.; vi) Introduzir o balanço de custos e benefícios na anulação de um processo; vii) Criar a responsabilidade objetiva dos partidos políticos pelo caixa 2, lavagem de dinheiro.

Primeiro, cabe destacar as sugestões de mudanças nas penas e nos tipos penais. O MPF acredita que aumentar penas para casos de corrupção e tornar crime hediondo a corrupção de altos valores seriam modos de combate à corrupção. Nota-se, nesse discurso, um sentido de expansão do Direito Penal que, em vez de cingir-se a tutelar os bens jurídicos essenciais da sociedade, vem a defender a moralidade administrativa e o desenvolvimento econômico (lato sensu) do país. Acredita-se, de forma errônea, que aumentar as penas para os casos de corrupção fará com que os corruptos pensem "duas vezes" antes de cometer o delito. Essa sugestão busca atingir duas frentes: atender aos anseios contra a impunidade dos corruptos e aumentar a visão de "prevenção geral" da pena. A hediondização do crime, por sua vez, atinge de forma mais ampla o plano simbólico da Ciência Criminal do que efetivamente o plano real do processo penal, considerando que, por meio dessa alteração, assinala-se a sociedade que esse tipo de crime é algo inaceitável durante a vigência do ordenamento repressivo em terra brasilis.

A título de exemplo, pode-se trazer à tona a motivação de uma dessas sugestões, na qual o MPF afirma que "a criminalização do enriquecimento ilícito garante que o agente não fique impune mesmo quando não for possível descobrir ou comprovar quais foram os atos específicos de corrupção praticados." 67 Nota-se pela leitura desse trecho a mudança das regras do jogo processual. Ora, se é a acusação que tem o dever de provar, por que "condenar" alguém sem ter o lastro probatório suficiente para imputar algum crime ao agente? Já abrindo-se esse azo, por que não investigar todas as "grandes fortunas" do Brasil, selecionando os indivíduos que não fizeram suas declarações de imposto de renda a contento, de forma suficiente, e garantir sua "condenação"? Dessa forma, busca-se, por meio de uma flexibilização de garantias constitucionais, combater a corrupção, algo nitidamente

\footnotetext{
67 BRASIL. MINISTÉRIO PÚBLICO FEDERAL. Sumário Executivo - 10 Medidas para combater a corrupção e impunidade. <http://noticias.pgr.mpf.mp.br/noticias/noticias-dosite/copy_of_pdfs/sumario\%20executivo\%20das\%20medidas.pdf>. Acesso em: 1 abr. 2015.
} 
SILVA, Lucas do Monte. O corrupto como inimigo no direito penal brasileiro. Revista Eletrônica Direito e Política, Programa de Pós-Graduação Stricto Sensu em Ciência Jurídica da UNIVALI, Itajaí, v.10, n.3, $2^{\circ}$ quadrimestre de 2015. Disponível em: www.univali.br/direitoepolitica - ISSN 19807791.

inconstitucional.

Ocorre que o problema da corrupção, no Brasil, não tem a ver estritamente com suas leis, caso houvesse, seria por motivo contrário, isto é, pelo excesso de leis. A celeuma cinge-se à fiscalização ${ }^{68}$. O sujeito que pratica um crime de corrupção, antes de se preocupar com a pena caso seja flagrado pela autoridade policial, busca analisar o nível de fiscalização que o seu ato passará. Em outras palavras: um servidor público de uma prefeitura municipal tenderá a não praticar o referido crime, caso saiba que o seu ato passará pela fiscalização interna e externa de outros setores, que verificarão a lisura do seu ato. Eis a questão. Os tipos penais existem, suas mudanças, de per se, não são necessárias. 0 ponto central deve ser os métodos de fiscalização, treinamento e fortalecimento dos setores responsáveis pela fiscalização, seja dos atos públicos ou privados. Não adianta possuir os tipos penais com penas extensas, em um exemplo ad absurdum, com pena de morte, por exemplo, caso a Polícia Federal, a Polícia Civil e os próprios Ministérios Públicos Federal e Estaduais não possuem o expertise, equipamento eletrônicos, softwares, que facilitem o trabalho de fiscalização. Afinal, o "homem somente viola a lei porque há uma certeza de impunidade e, por tal razão, o poder absoluto aporta como um instrumento hábil de dispersão do medo recíproco, sentimento próprio do estado de natureza, responsável pela precipitação das guerras que põem em risco a preservação da espécie humana"69

Segundo, também merecem destaque as propostas nitidamente parciais do Ministério Público, que buscam tão somente defender questões que "facilitam" seus trabalhos nos tribunais superiores. Por exemplo, sugere-se mudar as regras de apresentação de contrarrazões em segunda instância, revogação dos embargos infringentes, extinção da revisão do voto do relator no julgamento da apelação, mudança nas regras de embargos de declaração, do recurso

\footnotetext{
68 "As teorias expansionistas basicamente defendem que somente com uma atuação firme, rígida, multifacetada do Direito Penal será possível à sociedade exercer o necessário controle sobre uma nova forma de criminalidade" (GIACOMO, Roberta Catarina; MACHADO, Fábio Guedes de Paula. Novas teses dogmáticas jurídico-penais para a proteção do bem jurídico ecológico na sociedade do risco. Revista Liberdades, v. 2, p. 39-55, 2009, p. 42)

69 ALVES, Fábio Wellington Ataíde. Efetivação da garantia de defesa no estado constitucional de direito: colisão entre poder punitivo e garantia de defesa. 2008. Dissertação (Mestrado) Universidade Federal do Rio Grande do Norte. p. 189.
} 
SILVA, Lucas do Monte. O corrupto como inimigo no direito penal brasileiro. Revista Eletrônica Direito e Política, Programa de Pós-Graduação Stricto Sensu em Ciência Jurídica da UNIVALI, Itajaí, v.10, n.3, $2^{\circ}$ quadrimestre de 2015. Disponível em: www.univali.br/direitoepolitica - ISSN 19807791.

extraordinário e do habeas corpus em diversos dispositivos. Nesta sugestão busca-se limitar o direito de defesa em prol do direito da acusação, isto é, limitam-se os instrumentos processuais que são fornecidos para a defesa, para que o Ministério Público tenha um trabalho facilitado.

Nota-se de forma clara a criação da imagem do inimigo no "corrupto". As suas garantias processuais são minimizadas diante do poder acusatório. Nesse sentido, oportuno destacar que "não se pode negar que o fenômeno da expansão por diversas vezes se demonstra como espécie de perversidade estatal e que o recurso ao Direito Penal, por diversas vezes, constitui-se como fácil expediente ao qual os poderes públicos recorrem para fazer frente a problemas sociais de grande envergadura" ${ }^{\prime 70}$.

Terceiro, o MPF recomenda restringir as nulidades processuais a casos em que são necessários, por meio da introdução do balanço de custos e benefícios na anulação de um processo. No caso vertente, busca-se a subjetivização de elementos objetivos. Ora, caso um processo tenha como elemento probatório uma prova ilícita, deve ser anulado, tendo em vista os direitos do réu que foram violados na obtenção da referida prova. É evidente que existirão Juízes, sobretudo anacrônicos com visões anti-CFRB/88, que não declararão a nulidade do processo, tendo por base o balanço de custos e benefícios que o MPF sugere. Isso já ocorre, no entanto, suas ações acabarão por ser legitimadas pelo ordenamento jurídico. A política criminal "levada a efeito num Estado democrático de direito não pode contrastar com os valores e diretrizes constitucionais. De forma que as opções político-criminais partem das fontes criminológicas, mas não cruzam os limites impostos pela Constituição"71

Dessa forma, tem-se:

a proposta de flexibilização dos instrumentos dogmáticos e das regras de atribuições de responsabilidades, a fim de que o Direito Penal angarie condições para atuar na proteção aos

70 GIACOMO, Roberta Catarina; MACHADO, Fábio Guedes de Paula. Novas teses dogmáticas jurídico-penais para a proteção do bem jurídico ecológico na sociedade do risco. Revista Liberdades, v. 2, p. 39-55, 2009, p. 42.

71 GUIMARÃES, Isaac Sabbá. Ativismo judicial e o problema metodológico da discricionariedade judicial para a formação de uma política criminal. Revista Eletronica Direito e Política, Programa de Pós- Graduação Stricto Sensu em Ciência Jurídica da UNIVALI, Itajaí, v.9, n.3, 2014, p. 1354. 
SILVA, Lucas do Monte. O corrupto como inimigo no direito penal brasileiro. Revista Eletrônica Direito e Política, Programa de Pós-Graduação Stricto Sensu em Ciência Jurídica da UNIVALI, Itajaí, v.10, n.3, $2^{\circ}$ quadrimestre de 2015. Disponível em: www.univali.br/direitoepolitica - ISSN 19807791.

bens jurídicos supra-individuais e no controle dos novos fenômenos do risco, já que nesta concepção ele é a condição de estabilidade da sociedade do risco, posição esta desenvolvida neste trabalho. ${ }^{72}$

O balanço de custos e benefícios busca trazer a ideia de ponderação de interesse para a seara processual penal. Ocorre que não há razão para isso. Sempre o direito de defesa e suas inerentes garantias constitucionais deverão prevalecer diante do direito de acusação. Essa é a base do Estado Democrático de Direito. ${ }^{73}$ Caso contrário, a autoridade policial violará diariamente os direitos dos cidadãos, e, caso ache algo punível, afirmará que os benefícios para a população deverão prevalecer em relação ao direito do cidadão. ${ }^{74}$

Nos dizeres do Min. Eros Grau:

Contra "bandidos" o Estado e seus agentes atuam como se bandidos fossem, à margem da lei, fazendo mossa da Constituição. E tudo com a participação do juiz, ante a crença generalizada de que qualquer violência é legítima se praticada em decorrência de uma ordem judicial. Juízes que se pretendem versados na teoria e prática do combate ao crime, juízes que arrogam a si a responsabilidade por operações policiais transformam a Constituição em um punhado de palavras bonitas rabiscadas em um pedaço de papel sem utilidade prática, como diz FERRAJOLI. ${ }^{75}$

72 GIACOMO, Roberta Catarina; MACHADO, Fábio Guedes de Paula. Novas teses dogmáticas jurídico-penais para a proteção do bem jurídico ecológico na sociedade do risco. Revista Liberdades, v. 2, p. 39-55, 2009, p. 41.

73 Nesse sentido, importante ressaltar o seguinte questioanamento de Baratta, que sintetiza essa questão: "¿Queremos ser defensores del orden, o custodia de los derechos humanos?" (BARATTA, Alessandro. Criminología y Sistema Penal - Compilación in memoriam. Buenos Aires: Euros, 2004.)

74 "O combate à criminalidade, garantia da segurança pública, inevitavelmente entra em testilhas, em certos momentos, com pretensões, legítimas ou não, de direito individual. Eis porque nos Estados de direito há, à disposição dos cidadãos, um Poder Judiciário independente, com a função de arbitrar esses conflitos, declarando ao indivíduo quais constrangimentos o ordenamento jurídico o obriga a suportar, quais os que se não lhe pode impor." O Ministro ainda conitnua afirmando que "isso tem sido no entanto ignorado nos dias que correm, de sorte que alguns juízes se envolvem direta e pessoalmente com os agentes da Administração, participando do planejamento de investigações policiais que resultam em ações penais de cuja apreciação e julgamento eles mesmos serão incumbidos, superpondo os sistemas inquisitório e misto, a um tempo só recusando o sistema acusatório." (Habeas Corpus 95.009-4 SP. Rel. Min. Eros Grau)

75 Habeas Corpus 95.009-4 SP. Rel. Min. Eros Grau. 
SILVA, Lucas do Monte. O corrupto como inimigo no direito penal brasileiro. Revista Eletrônica Direito e Política, Programa de Pós-Graduação Stricto Sensu em Ciência Jurídica da UNIVALI, Itajaí, v.10, n.3, $2^{\circ}$ quadrimestre de 2015. Disponível em: www.univali.br/direitoepolitica - ISSN 19807791.

Quarto, por fim, o MPF também sugere criar uma responsabilidade objetiva dos partidos políticos pelo caixa 2, lavagem de dinheiro. Neste caso, busca-se tornar uma exceção, a responsabilização objetiva, em regra, para esses casos. Flores salienta que "as novas técnicas de tutela penal têm acarretado a imputação da responsabilidade penal sem que haja uma relação direta, com algum grau relevante, de afetação ao bem jurídico protegido pela norma penal."76

Salientando o autoritarismo, escondido por trás do discurso democrático, Warat anota que: "

Para que nos serve um saber que não tenha competência para denunciar e colocar em crise os momentos em que o respeito à lei funciona como simulação de uma sociedade democrática? O autoritarismo mais eficiente é o que consegue diluir-se, confundir-se no interior de uma proposta discursivamente democrática. Uma proposta teórica como a de Kelsen tem uma enorme responsabilidade frente a atos autoritários simulados. ${ }^{77}$

Conforme ressalta Baratta, essa maior criminalização de atividades com maior nocividade social possui legitimação pela sociedade. Nesse contexto, as classes subalternas:

"(...) estão interessadas, ao mesmo tempo, em um decidido deslocamento da atual política criminal, em relação a importantes zonas de nocividade social ainda amplamente deixadas imunes do processo de criminalização e de efetiva penalização (pense-se na criminalidade econômica, na poluição ambiental, na criminalidade política dos detentores do poder, na máfia, etc.), mas socialmente muito mais danosas, em muitos casos, do que o desvio criminalizado e perseguido. Realmente, as classes subalternas são aquelas selecionadas negativamente pelos mecanismos de criminalização". ${ }^{78}$

76 MARCANTE FLORES, Marcelo. Crimes de colarinho branco e a formação do Direito Penal secundário: os desafios da política criminal contemporânea. Tribuna Virtual do IBCCRIM. Edição No. 5, 2013, p. 39.

77 WARAT, Luis Alberto. Introdução geral ao direito: a epistemologia jurídica da modernidade. Porto Alegre: Sérgio Antonio Fabris Editor. p. 260. v. 2

78 BARATTA, Alessandro. Criminologia crítica e crítica do direito penal: introdução à sociologia do direito. Rio de Janeiro: Revan, 2002, p. 197-198. 
SILVA, Lucas do Monte. O corrupto como inimigo no direito penal brasileiro. Revista Eletrônica Direito e Política, Programa de Pós-Graduação Stricto Sensu em Ciência Jurídica da UNIVALI, Itajaí, v.10, n.3, $2^{\circ}$ quadrimestre de 2015. Disponível em: www.univali.br/direitoepolitica - ISSN 19807791.

Ainda nesse sentido, Santos Júnior anota que "o verdadeiro crime organizado mata, silenciosamente, dezenas de milhares de pessoas todos os anos", pelas pessoas que acabam "sonegando ou desviando verbas públicas que poderiam ser utilizadas na construção de hospitais, escolas, estradas e casas populares"79. Ora, Sutherland aponta que o "financial cost of white-collar crime is probably several times as great as the financial cost of all the crimes which are customarily regarded as the crime-problem." ${ }^{80}$

O processo de imagem do inimigo possui legitimação pela sociedade e sua forma de configuração. Nesse sentido, Mussig anota que "o problema de la legitimación del Derecho penal - cuál es el sentido social, cuál el objeto de cada tipo penal individual - aparece como cuestión directamente relacionada con la configuración de la sociedad", e não como "una cuestión relativa a determinados bienes jurídicos". Por fim, arremata, afirmando que "el Derecho penal es garantía del Derecho en cuanto estructura de la sociedad." ${ }^{81}$.

No entanto, em que pese tenha ocorrido um aumento (mesmo que ainda não tenha chegado aos níveis desejáveis) da fiscalização e da criação da imagem do inimigo nos praticantes da corrupção, os sujeitos ativos dos "crimes de colarinho branco, se valem do poder e da influência para que crimes sejam mais facilmente cometidos e, também, uma vez praticados, para que não sejam sancionados." 82 .

No entanto, oportuno ressaltar que, no campo da Criminologia Crítica, o corrupto não pode ser considerado um inimigo, simplesmente porque ainda não passou pelo terceiro processo migratório na construção da imagem do inimigo. Para Alvino Sá, há três processos migratórios na construção da figura do inimigo, na

79 SANTOS JÚNIOR, Rosivaldo Toscano dos. Discurso sobre e o sistema penal - uma visão crítica. Revista Direito e Liberdade. v. 3, n. 2, p. 629 - 654 - set 2006, 647-648

80 SUTHERLAND, Edwin H. White Collar Criminality. American Sociological Review. 1940;5:1-12, p. 7.

81 MÜSSIG, Bernd. Desmaterialización del bien jurídico y de la política criminal: sobre las perspectivas y los fundamentos de uma teoría del bien jurídico crítica hacia el sistema. Tradução de Manuel Cancio Meliá e Enrique Peñaranda Ramos. Colombia: Universidad Externado de Colombia, 2001. p. 171-172).

82 ANTUNES, Leonardo Leal Peret. A expansão do direito penal na era da globalização e a criminalidade moderna. Tribuna Virtual do IBCCRIM. v. 1, p. 54-72, 2013, p. 63. 
SILVA, Lucas do Monte. O corrupto como inimigo no direito penal brasileiro. Revista Eletrônica Direito e Política, Programa de Pós-Graduação Stricto Sensu em Ciência Jurídica da UNIVALI, Itajaí, v.10, n.3, $2^{\circ}$ quadrimestre de 2015. Disponível em: www.univali.br/direitoepolitica - ISSN 19807791.

pessoa do deliquente: a) criação do inimigo coletivo; b) criação do inimigo como ser estranho, diferente; c) criação da autoimagem de inimigo ${ }^{83}$.

O corrupto, conforme pode ser registro pela análise dos discursos dos "homens de bem", visto alhures, pode ser considerado um inimigo coletivo. $O$ inimigo individual é internalizado pela coletividade e transformado em massa crítica na criação do inimigo coletivo, permeado de emoções e paixões. Essas emoções e paixões puderam ser verificadas no protesto de 15 abril de março de 2015, no qual milhões de brasileiros promoveram manifestações anti-corrupção.

Em seguida, pode-se observar a criação do inimigo como ser diferente. Os pretensos "homens de bem"/honestos são separados dos corruptos, indivíduos diferentes que não merecem fazer "parte" de uma sociedade. O comportamento dos criminosos, que, em sua maioria, são políticos, são julgados como seres estranhos à sociedade. Em que pese o Brasil utilize a democracia representativa, os deputados, senadores, governadores, prefeitos são vistos como seres diferentes, que englobados na classe de "políticos", são vistos, prima facie, como corruptos, mesmo que não haja qualquer indício dessa situação. Neste caso, "torna-se inevitável o afloramento do (primitivo) sentimento de justiça, não baseado na razão e na moral, mas impulsionado pelo instinto de defesa.". ${ }^{84}$

No entanto, o inimigo, na visão da criminologia crítica, não pode ser considerado um inimigo, pois não possui uma "autoimagem de inimigo". O corrupto que é definido como inimigo da sociedade não se vê como inimigo. As experiências do político em seu ambiente, seja no Congresso Nacional, seja nas Assembleias Legislativas, não alimentam continuamente nele o autoconceito, seu self, que "corresponde à forma como o indivíduo se percebe em suas experiências em face do campo fenomenal", 85 pelo contrário, o político acredita que está cumprindo seu papel.

\footnotetext{
83 SÁ, Alvino Augusto de. Desafios da execução penal. In Boletim IBCCRIM. São Paulo: IBCCRIM, ano 20 , n. 238, p. 16-17, set, 2012.

84 SÁ, Alvino Augusto de. Desafios da execução penal. In Boletim IBCCRIM. São Paulo : IBCCRIM, ano 20, n. 238, p. 16-17, set, 2012.

85 SÁ, Alvino Augusto de. Desafios da execução penal. In Boletim IBCCRIM. São Paulo : IBCCRIM, ano 20, n. 238, p. 16-17, set, 2012.
} 
SILVA, Lucas do Monte. O corrupto como inimigo no direito penal brasileiro. Revista Eletrônica Direito e Política, Programa de Pós-Graduação Stricto Sensu em Ciência Jurídica da UNIVALI, Itajaí, v.10, n.3, $2^{\circ}$ quadrimestre de 2015. Disponível em: www.univali.br/direitoepolitica - ISSN 19807791.

\section{CONSIDERAÇÕES FINAIS}

A partir do exposto, conclui-se que, sob a óptica do Direito Penal e da Política Criminal adotada no cenário brasileiro, o corrupto pode ser sim considerado um inimigo. Ressalta-se, no entanto, que mesmo sendo possível fazer essa afirmativa, trata-se de uma questão nova, amplificada pelo Direito Penal de reação, mormente no que se refere ao alarmismo da mídia quanto ao crescimento da corrupção, de forma que os casos concretos e leis eficazes sobre o assunto ainda são incipientes. Tais conclusões vão de encontro com os postulados da criminologia crítica, na qual o corrupto não deve ser considerado um inimigo, tendo em vista que este não passou pela terceira fase do processo migratório da imagem do inimigo, no delinquente, qual seja, que ele tenha uma autoimagem de inimigo.

O senso comum midiático, com base na ideologia da defesa social, engendra uma divisão da sociedade entre os "homens de bem", que representam o bem, e os "marginais"/"inimigos", os quais, por sua vez, representam o mal. No entanto, não apresenta um fundamento básico, tampouco conceitos, para que possa ser feita essa diferenciação. Observou-se que as pretensas "pessoas de bem" praticam crimes ou contravenções penais, semanalmente, senão, diariamente, mas, no entanto, não são consideradas "marginais" por elas mesmas ou por terceiros. Isso ocorre devido à aceitação social da conduta, muitas vezes considerada tão somente um "jeitinho", conforme pode ser observado, por exemplo, no caso de motoristas que dirigem após o consumo de bebida alcoólica. Ocorre que, no Direito Penal, o inimigo por ser considerado um inimigo, acaba por ter suas garantias constitucionais minimizadas para combater o perigo abstrato à sociedade. A título de exemplo, citaram-se as inconstitucionais sugestões de mudanças do MPF, com objetivo de combater a corrupção, que, de modo implícito e explícito, busca mudar as regras do jogo processual em prol da acusação, de maneira que o Estado se valesse de medidas radicais, em muitos casos ilegais e inconstitucionais, para diminuir as garantias constitucionais, aumento desproporcional de penas, antecipação da tutela penal etc.

Por fim, quanto à inadequação da atual política criminal voltada à perseguição de corruptos, conclui-se que essa situação ocorre por três motivos. 
SILVA, Lucas do Monte. O corrupto como inimigo no direito penal brasileiro. Revista Eletrônica Direito e Política, Programa de Pós-Graduação Stricto Sensu em Ciência Jurídica da UNIVALI, Itajaí, v.10, n.3, $2^{\circ}$ quadrimestre de 2015. Disponível em: www.univali.br/direitoepolitica - ISSN 19807791.

Primeiro, considerando que com sua popularização abre-se azo para violações ao Estado Democrático de Direito, tendo base em álibis teóricos como "interesse público" e "ordem pública". Na busca pelo corrupto, assim, não importaria a origem ilícita da prova ou a violação de garantias fundamentais, contanto que o Estado consiga "defender" a população, os pretensos "homens de bem", da corrupção.

Segundo, ainda com base nessa preocupação, cabe ressaltar a amplitude do bem jurídico a ser tutelado, a moralidade administrativa. Embora possa ser considerado um bem jurídico axiologicamente relevante para o Direito Penal, se trata de um "valor" que deve ser tutelado anteriormente ao crime, por meio de outras áreas como o Direito Administrativo e Direito Civil, mediante o uso de instrumentos jurídicos ou não, que facilitem a fiscalização dos atos públicos; e, não, a posteriori, como ocorre no caso do Direito Penal.

Terceiro, agora na área da Criminologia crítica, porque o corrupto não se considera um "inimigo", mas sim uma pessoa que está cumprindo seu papel e que, diante de determinadas "oportunidades" fez o que a maioria dos seus pares faria.

\section{REFERÊNCIAS DAS FONTES CITADAS}

ALMEIDA, Alberto Carlos. A cabeça do brasileiro. 2.ed. Rio de Janeiro: Record, 2007.

ALVES, Fábio Wellington Ataíde. A importan̂ncia da postura do juiz criminal para a defesa do regime constitucional de proteção à liberdade. Revista Direito e Liberdade, v. 6, n. 2, p. $69-84-$ jan/jun 2007.

Efetivação da garantia de defesa no estado constitucional de direito: colisão entre poder punitivo e garantia de defesa. 2008. Dissertação (Mestrado)_ - Universidade Federal do Rio Grande do Norte.

ANTUNES, Leonardo Leal Peret. A expansão do direito penal na era da globalização e a criminalidade moderna. Tribuna Virtual do IBCCRIM. v. 1, p. 54-72, 2013.

BARATTA, Alessandro. Criminologia crítica e crítica do direito penal: introdução à sociologia do direito. Rio de Janeiro: Revan, 2002 
SILVA, Lucas do Monte. O corrupto como inimigo no direito penal brasileiro. Revista Eletrônica Direito e Política, Programa de Pós-Graduação Stricto Sensu em Ciência Jurídica da UNIVALI, Itajaí, v.10, n.3, $2^{\circ}$ quadrimestre de 2015. Disponível em: www.univali.br/direitoepolitica - ISSN 19807791.

. Criminología y Sistema Penal - Compilación in memoriam. Buenos Aires: Euros, 2004.

BAUMAN, Zygmunt. Modernidade e Ambivalência. Rio de Janeiro: Jorge Zahar Editor. 1999.

BECK, Ulrich. Incertezas fabricadas - Entrevista com o sociólogo alemão Ulrich Beck. Disponível em: <http://www.jinnyat.com.br/artigos/a_sociedade_de_risco.pdf>. Acesso em: 15 jul 2015

BIZARRIA, Breno Timbó Magalhães. O direito penal do inimigo aplicado a um estado democrático de direito. Revista Acadêmica da Escola Superior do Ministério Público do Estado do Ceará. Fortaleza, ano 4. n.2 ago./dez. 2012.

BRASIL. MINISTÉRIO PÚBLICO FEDERAL. Caso Lava Jato. Disponível em: <http://www.lavajato.mpf.mp.br>. Acesso em: 30 mar. 2015.

Sumário Executivo - 10 Medidas para combater a corrupção e impunidade. <http://noticias.pgr.mpf.mp.br/noticias/noticias-dosite/copy_of_pdfs/sumario\%20executivo\%20das\%20medidas.pdf>. Acesso em: 1 abr. 2015.

BUSATO, Paulo César. Bases de uma teoria do delito a partir da filosofia da linguagem. Revista Direito e Liberdade, v. 14, n. 1, p. 241-264, jan./jun. 2012.

CRUZ, Paulo Márcio; GLASENAPP, Maikon Cristiano. Governança e sustentabilidade: constituindo novos paradigmas na pós-modernidade. Revista Direito e Liberdade, Natal, v. 16, n. 2, p. 163-186, maio/ago. 2014. Quadrimestral.

DIAS, Jorge de Figueiredo. O papel do direito penal na proteção das gerações futuras. Boletim da Faculdade de Direito da Universidade de Coimbravolume comemorativo do $7^{\circ}$ Volume, Coimbra (2003): 1123-1138.

Temas básicos da doutrina penal. Coimbra: Coimbra, 2001.

DIAS, Maria da Graça dos Santos; MELO, Osvaldo Ferreira de; SILVA, Moacyr Motta da. Política jurídica e pós-modernidade. Florianópolis: Conceito Editorial, 2009.

GHIZZO NETO, Affonso. Corrupção, Estado Democrático de Direito e Educação. 2008. 290 f. Dissertação (Mestrado em Direito) - Universidade Federal de Santa Catarina, Santa Catarina,

GIACOMO, Roberta Catarina; MACHADO, Fábio Guedes de Paula. Novas teses dogmáticas jurídico-penais para a proteção do bem jurídico ecológico na sociedade do risco. Revista Liberdades, v. 2, p. 39-55, 2009. 
SILVA, Lucas do Monte. O corrupto como inimigo no direito penal brasileiro. Revista Eletrônica Direito e Política, Programa de Pós-Graduação Stricto Sensu em Ciência Jurídica da UNIVALI, Itajaí, v.10, n.3, $2^{\circ}$ quadrimestre de 2015. Disponível em: www.univali.br/direitoepolitica - ISSN 19807791.

GIDDENS, A. As Conseqüências da Modernidade. São Paulo: Editora da Universidade Estadual Paulista, 1991.

GRECO, Luís. Sobre o chamado Direito Penal do Inimigo. Revista da Faculdade de Direito de Campos, Ano VI, No 7 - Dezembro de 2005. p. 214.

GUIMARÃES, Isaac Sabbá. Ativismo judicial e o problema metodológico da discricionariedade judicial para a formação de uma política criminal. Revista Eletrónica Direito e Política, Programa de Pós- Graduação Stricto Sensu em Ciência Jurídica da UNIVALI, Itajaí, v.9, n.3, 2014.

JAKOBS, Günther e MELIÁ Mauel Cancio. Direito Penal do Inimigo: Noções e Críticas. 6. ed. - Porto Alegre: Livraria do Advogado Editora, 2012.

LUZ, Yuri Corrêa da. Entre bens jurídicos e deveres normativos: um estudo sobre os fundamentos do direito penal contemporâneo. 1.ed. - São Paulo: IBCCRIM, 2013

MACHADO, Édina Maria dos Santos. A administrativização do direito penal em face da sociedade do risco e a flexibilização dos princípios e garantias jurídicopenais. Revista de Ciências Jurídicas, Ponta Grossa, 4(1): 67-75, 2012. Disponível em: <http://http://www.revistas2.uepg.br/index.php/lumiar>. Acesso em: 6 mar. 2015

MARCANTE FLORES, Marcelo. Crimes de colarinho branco e a formação do Direito Penal secundário: os desafios da política criminal contemporânea. Tribuna Virtual do IBCCRIM. Edição No. 5, 2013.

MÜSSIG, Bernd. Desmaterialización del bien jurídico y de la política criminal: sobre las perspectivas y los fundamentos de uma teoría del bien jurídico crítica hacia el sistema. Tradução de Manuel Cancio Meliá e Enrique Peñaranda Ramos. Colombia: Universidad Externado de Colombia, 2001.

PRAZERES, José de Ribamar Sanches. O Direito Penal Simbólico Brasileiro. Disponível em: <www.sedep.com.br/?idcanal=24849>. Acesso em: 23 mar. 2015.

REALE JUNIOR, Miguel. Instituições de Direito Penal: parte geral. V. 1. Rio de Janeiro: Forense, 2004.

ROXIN, Claus. Politica criminal y Sistema del derecho penal. 2. ed. Buenos Aires: Hammurabi, 2002.

SANTOS, Juarez Cirino do. O direito penal do inimigo - ou o discurso do direito penal desigual. Disponível em: <http://www.cirino.com.br/artigos/jcs/Direito\%20penal\%20do\%20inimigo.pdf>. Acesso em: 25 mar. 2015. 
SILVA, Lucas do Monte. O corrupto como inimigo no direito penal brasileiro. Revista Eletrônica Direito e Política, Programa de Pós-Graduação Stricto Sensu em Ciência Jurídica da UNIVALI, Itajaí, v.10, n.3, $2^{\circ}$ quadrimestre de 2015. Disponível em: www.univali.br/direitoepolitica - ISSN 19807791.

SANTOS JÚNIOR, Rosivaldo Toscano dos. Discurso sobre e o sistema penal uma visão crítica. Revista Direito e Liberdade. v. 3, n. 2, p. 629 - 654 - set 2006

SILVA SÁNCHEZ, Jesús-María. A expansão do Direito Penal: aspectos da política criminal nas sociedades pós-industriais. São Paulo: Revista dos Tribunais, 2002.

SÁ, Alvino Augusto de. Desafios da execução penal. In Boletim IBCCRIM. São Paulo : IBCCRIM, ano 20, n. 238, p. 16-17, set, 2012.

SILVA, Nailton Gomes. Método para compor e avaliar argumentos jurídicos. Revista Direito e Liberdade, Natal, v. 16, n. 3, p. 189-226, set./dez. 2014. Quadrimestral.

SOUZA, Paulo de Andrade e. O Direito Penal do Inimigo e o Garantismo Penal. Escola da Magistratura do Estado do Rio de Janeiro. 2012. Disponível em: http://www.emerj.tjrj.jus.br/paginas/trabalhos_conclusao/1semestre2012/trabal hos_12012/paulaandradesouza.pdf>. Acesso em: 26 mar. 2015.

STRECK, Lênio. L. Hermenêutica Jurídica $\mathbf{e ( m ) ~ C r i s e . ~ 1 0 . e d . ~ P o r t o ~ A l e g r e : ~}$ Livraria do Advogado, 2011

WARAT, Luis Alberto. Introdução geral ao direito: a epistemologia jurídica da modernidade. Porto Alegre: Sérgio Antonio Fabris Editor. p. 260. v. 2.

WEBER, Max. A política como vocação. In: Ciência e política: duas vocações. São Paulo, Cultrix, 2000.

Submetido em: Abril/2015

Aprovado em: Julho/2015 